\title{
Temporal variation in toxic bait, carbohydrate and protein preference and toxic bait efficacy in Argentine (Linepithema humile) and Darwin's ants (Doleromyrma darwiniana)
}

\author{
A thesis submitted in the fulfilment \\ of the requirements for the degree of \\ Master of Science in Ecology and Biodiversity \\ At Victoria University of Wellington
}

June 2011

By Melissa Rubina Mathieson 


\section{Abstract}

By determining if there is any temporal variation in toxic bait, carbohydrate and protein preference in Argentine and Darwin's ants, we can provide better control options because we can identify with more accuracy when ants will be foraging for one food type over another. Improving our understanding is also fundamental as we can improve future bait formulations, bait application and timing, and increase levels of bait uptake. I have two aims in this thesis. First, I investigated toxic bait, carbohydrate and protein preferences for Argentine ants (Linepithema humile) and Darwin's ant (Doleromyrma darwiniana). The second aim in my thesis was to examine the efficacy of toxic baits in laboratory colonies of Argentine ants. Food preferences varied between species and within species considerably throughout the year, although Darwin's ant consistently favoured foods higher in carbohydrates. Argentine ants showed a significant preference for protein over carbohydrates during December and January. Despite differences in carbohydrate and protein preferences the preference for individual toxic baits showed little temporal variation. The toxic bait efficacy experiment revealed that Xstinguish ${ }^{\mathrm{TM}}$ and Exterm-an-Ant ${ }^{\circledR}$ baits produced the highest mortality rate. Other commercially available toxic baits had little effect on workers or queens. The efficacy of the toxic baits was influenced by the starvation level of the ant colonies, and only the colonies that were starved for 48 hours experienced a $100 \%$ mortality rate. Due to these results, I recommend that bait application with Xstinguish ${ }^{\mathrm{TM}}$ and Exterm-an-Ant ${ }^{\circledR}$ in late winter-spring would be optimal as this time frame is when ants are likely to be starved, and when foraging activity is increasing, thus maximising the chances of bait uptake. A second round of baiting treatment with both baits (Xstinguish ${ }^{\mathrm{TM}}$ and Exterm-an-Ant ${ }^{\circledR}$ ) in summer when Argentine ants have been shown to undergo a second wave of reproduction could also be beneficial. 


\section{Acknowledgments}

I would firstly like to thank Phil Lester and Richard Toft, for all the help, advice and encouragement. They have both provided much needed support for me while I have been studying extramurally and have always been available to help me out. I would also like to thank Dalice Sims, for all of her help and patience with statistical analysis.

I would also like to thank Lindsay Vaughan for his initial suggestion on doing a Masters project on Argentine and Darwin's ants and all of his encouragement and enthusiasm in finding out a way to stop these ants! I am also extremely grateful to all the generous residents in the Nelson region that let me come and go as I pleased to do my experiments.

A big thank you to the New Zealand Biosecurity Institute and Victoria University of Wellington for providing funding to help with my research.

Lastly I want to thank all my family and friends who have been so encouraging and supportive and even helped out with some of the more odd tasks like feeding my pet ants. Your support has been fundamental in my completion of this work. 


\section{Table of Contents}

Abstract 2

Acknowledgments 3

Table of Contents 4

List of Tables and Figures $\quad 6$

$\begin{array}{ll}\text { Chapter } 1 & 7\end{array}$

$\begin{array}{ll}\text { General introduction } & 7\end{array}$

Research Aims 11

Chapter $2 \quad 13$

Toxic bait, carbohydrate and protein preference in the Argentine ant (Linepithema humile) and Darwin's ant (Doleromyrma darwiniana) in New Zealand. 13

$\begin{array}{ll}\text { Abstract } & 13\end{array}$

$\begin{array}{ll}\text { Introduction } & 14\end{array}$

Materials and methods $\quad 16$

$\begin{array}{ll}\text { Study site } & 16\end{array}$

$\begin{array}{ll}\text { Field methods } & 17\end{array}$

$\begin{array}{ll}\text { Statistical analysis } & 19\end{array}$

$\begin{array}{ll}\text { Results } & 21\end{array}$

Toxic bait preference $\quad 21$

$\begin{array}{ll}\text { Carbohydrate and protein preference } & 27\end{array}$

$\begin{array}{ll}\text { Discussion } & 34\end{array}$

Toxic bait preference $\quad 34$

Carbohydrate and protein preference 36 
Chapter 3

Toxic bait efficacy in laboratory colonies of the Argentine ant (Linepithema humile) 41

Abstract

Introduction

Materials and methods

Statistical analysis

Results

Discussion 50

Toxic bait efficacy 50

Level of starvation and its influence on bait uptake and mortality rate 52

Chapter 4

General discussion

Future research

60

Literature cited

61

Appendix 1: An experiment to examine Darwin's ants' protein preference 65 


\section{List of Tables and Figures}

Figure 1.1: Experimental locations in Nelson-Tasman region 16

Figure 1.2a: Photograph of toxic baits preference experiment 19

Figure 1.2b: Photograph of carbohydrate and protein preference experiment 19

Figure 1.3: Mean number of Argentine ants on different toxic baits 23

Figure 1.4: Mean number of Darwin's ants on different toxic baits 23

Table 1.1: Statistical analysis of Argentine ant's toxic bait preference 24

Table 1.2: Statistical analysis of Darwin's ant's toxic bait preference 26

Figure 1.5: Mean number of Argentine ants on different protein concentrations 29

Figure 1.6: Mean number of Argentine ants on different sucrose concentrations 30

Figure 1.7: Mean number of Darwin's ants on different food concentrations 30

Table 1.3: Statistical analysis of Argentine ant's food preference 31

Table 1.4: Statistical analysis of Darwin's ant's food preference 33

Figure 2.1a, 2.1b: Nest box set up $\quad 45$

Table 2.1: Cox's proportional hazards model of toxic bait and starvation treatments 48

Figure 2.2a: 24 hour treatment with worker ants mortality rates $\quad 48$

Figure 2.2b: 24 hour treatment with queen ants mortality rates 49

Figure 2.3a: 48 hour treatment with worker ants mortality rates 49

Figure 2.3b: 48 hour treatment with queen ants mortality rates 50

Figure 3.1: Mean number of Darwin's ants on different protein sources 67 


\section{Chapter 1:}

\section{General introduction}

The control of invasive ants is necessary due to the negative effects they have on people, other organisms and ecosystems. The spread of invasive species often results in a loss of biodiversity as native organisms are outcompeted and thus excluded from their habitat. Control of invasive ants is necessary in environments where native organisms and ecosystems have no natural defence mechanisms and invasive ants can take over an ecosystem through habitat displacement, competition and aggression (Harris 2002; Suarez et al. 2000; Human and Gordon 1996; Human and Gordon 1997). Invasive ants are also directly disruptive to people by infesting gardens and orchards, nesting inside homes, and invading food stores. Invasive ants can also have negative economical consequences such as threatening agricultural, crop and food sectors (Ward 2009; Ward et al. 2010; Vega and Rust 2001) and a potential loss of land value in infested areas.

Invasive ant species are often difficult to control due to characteristics that often include an aggressive and competitive nature, generalist diet, polygyny (multiple queens per colony), close association with humans and habitat flexibility (Harris 2002; Vega and Rust 2001). Common control methods of invasive ant species include the use of chemical sprays or toxic baits. The use of baits to control ant infestations is preferential to chemical sprays as the latter can often affect non target beneficial organisms (such as honeybees), mainly affect worker ants rather than the queens and larvae, and may be of a higher risk to the health of humans and the environment (Abril et al. 2007; Klotz and Shorey 2000; Stanley 2004). The successful control of invasive ants with toxic baits is largely limited by bait efficacy and uptake. An effective bait needs to be palatable and attractive, contain a low toxin level (so that the bait is nonrepellent), have a relatively long and stable field life and persist in a colony long enough to effect queens and larvae (Rust et al. 2004; Stanley 2004). Also the toxin must still be effective when diluted through the levels of the colonies via trophallaxis (Rust et al. 2004; Stanley 2004). Ant species require different food sources year round (Rust et al. 2000; Abril et al. 2007), so a bait that is tailored to their specific dietary requirements would maximize the chances of bait uptake (Stanley 2004). 
Seasonal changes in food preference of ant colonies are well documented and are strongly influenced by reproductive requirements. In field populations of Pheidole ceres, Judd (2005) found that during spring and summer, there was a high preference for protein due to the high levels of larvae in the nest, but that the colony preferred carbohydrates when reproductive adults were present. Red imported fire ants also regulate their food uptake based on larval needs (Cassill and Tschinkel 1999; Dussutour and Simpson 2008). Similarly Argentine ants protein and carbohydrate uptake is strongly linked to the reproductive phase of a colony and preference for protein sources has often been observed to increase in the spring months (Abril et al. 2007; Rust et al. 2000; Toft 2010).

Resource availability and its subsequent uptake also strongly influences ant colonies reproductive behaviour and colony growth. Kay et al. (2010) found that diet composition had a large influence on colony growth, whereby colonies on high protein, low carbohydrate diets had higher rates of worker mortality and smaller colonies compared to colonies fed on low protein and high carbohydrate diets. Other studies have shown that Argentine ants supplemented with intermediate and high levels of protein do not produce significantly more queens, males or worker pupae, suggesting a threshold whereby additional protein does not increase reproduction (Aron et al. 2001). These studies show that an excess of one food source over another is not as favorable for colony reproductive output as expected, and that a balanced amount of protein and carbohydrate uptake is necessary to maximize colony reproduction and reduce worker mortality rates.

Studies on Argentine ant's have determined their diet predominantly consists of liquid foods such as honeydew and nectar, with additions of protein sources such as insects (Markin 1970a; Vega and Rust 2001; Harris 2002; Abril et al. 2007; Rust et al. 2000). Darwin's ants have a similar preference for carbohydrates such as honeydew and have been observed feeding on prey (Taylor 1959; Keall 1979; Pers. Obs.). Argentine ants have been found carrying honeydew and nectar up to $99 \%$ of the time in a field population suggesting a frequent preference for liquid carbohydrates (Markin 1970a). 
The use of toxic baits are a popular method for the control of ant pests, because baits are directly ingested by worker ants and can then spread throughout an ant colony. Toxic baits are especially useful as they can target a specific species without affecting other organisms. For example, Argentine ants have been found to outcompete native ants at toxic baits thus maximising bait uptake in Argentine ants only (Buczkowski and Bennett 2008). The variety of toxic baits are diverse in their toxins, formulation and matrix. I chose to investigate the bait preference of Xstinguish ${ }^{\mathrm{TM}}$, Exterm-an-Ant $\AA$ and two DuPont ${ }^{\mathrm{TM}}$ products; Advion $\AA$ ant gel, DuPont ${ }^{\mathrm{TM}}$ Advion $\AA$ ant bait arena. These baits were chosen based on their availability and their diversity in bait formulation, attractant and toxin. All of these baits are widely available in New Zealand (with the exception of Advion ${ }^{\circledR}$ ant bait arena which was withdrawn from the market in 2010), and Xstinguish ${ }^{\mathrm{TM}}$, Exterm-an-Ant ${ }^{\circledR}$ and Advion $\AA^{\circledR}$ ant gel are frequently used by residents in the Tasman region (Pers. Obs). Xstinguish ${ }^{\mathrm{TM}}$ contains the toxin fipronil, Exterm-an-Ant $\AA$ contains boric acid and Advion $\AA$ ant gel and Advion $₫$ ant bait arena both contain indoxacarb. The toxins fipronil and boric acid are well studied in many ant species and have been shown to be highly effective at controlling Argentine ants (Toft and Rees 2009; Hooper-Bui and Rust 2000; Klotz et al. 2000; Rust et al. 2000; Klotz et al. 1998; Vega and Rust 2003), ghost ants (Ulloa-Chacon and Jaramillo 2003) and longlegged ants, Anoplolepis gracilipes (Chong and Lee 2009). The toxin indoxacarb has been found to be successful in the control of laboratory colonies of both red imported fire ants (Oi and Oi 2006) and Argentine ants (Toft and Rees 2009), but has been unsuccessful in the form of Advion ${ }^{\circledR}$ ant gel in reducing Argentine ant numbers (Toft and Rees 2009). A laboratory comparison of baits in Argentine ant colonies revealed that Xstinguish ${ }^{\mathrm{TM}}$ and Advion ${ }^{\circledR}$ ant bait arena provided a similar mortality rate as both baits contained a protein source which may suggest that the bait can reach the queens and larvae more effectively (Toft and Rees 2009). My goal was to compare the preference of four currently available toxic baits in field populations. There have been previous field studies on toxic bait preferences for Argentine ants (Krushelnycky et al. 1998) and crazy ants (Stanley and Robinson 2007), but neither of these studies used any of the commerical baits I tested. However, Stanley and Robinson (2007) did use $\mathrm{Xstinguish}^{\text {TM }}$ (the non-toxic monitoring version) and found it was highly attractive to crazy ants Anoplolepis gracilipes. Toxic bait preference does not necessarily mean a bait will be effective in killing an ant colony. The success of a toxic bait should be determined 
by its ability to kill an entire ant colony. Starvation levels of ant colonies can also influence bait uptake and subsequent mortality (O'Brien and Hooper-Bui 2005). I also investigated the efficacy of four toxic baits and the influence of starvation on mortality rates in laboratory colonies of Argentine ants.

Argentine ants are an invasive pest species from South America and they are now established in many countries all over the world (Wild 2004; Harris 2002). Darwin's ants are native to Australia, but are not regarded as a pest species there as they nest in the open country where urbanization is low (Keall 1979). In New Zealand both these ant species are regarded as pests. These ants have become well established pests since their introduction into New Zealand over 20 years ago (Harris 2002; Ward et al. 2010; Keall and Somerfield 1980; Keall 1979). Both species have thrived in warmer regions of the North Island and South Island and are largely distributed around cities with ports and coastal areas (Ward et al. 2010; Don 2007). These ant species are spread easily via human mediated routes such as the transport of infested pot plants and landscaping materials (Harris 2002; Suarez et al. 2001). They also infest gardens, nest inside homes, and invade food stores.

Argentine ants are disruptive to invertebrate communities through the displacement of other ant species (Harris 2002), by altering community food webs and thus reducing biodiversity (Suarez et al. 2000), and by competing with other ant species and invertebrates for resources and habitat (Harris 2002; Human and Gordon 1996; Human and Gordon 1997). These disruptions may have cascading effects on ecosystems because of the important roles many invertebrates play in ecosystem processes (Human and Gordon 1997; Ward et al. 2008).

It is not known whether Darwin's ants have similar detrimental effects on ecosystems and biodiversity, but it is a possibility given the large range and extent of infested sites (Pers. Obs.). Economically these ant species pose a possible threat to agricultural, crop and food sectors (Ward 2009; Ward et al. 2010; Vega and Rust 2001) and also a possible loss of land value in infested areas. Darwin's ants have received little attention in published literature (Shattuck 1999), however it is known that they do have a strong preference for sweet foods and due to this it is likely to be a serious threat to industrial and commercial companies producing sweet foods and also to vineyards and orchards 
(Keall 1979; Don 2007). Dead arthropods have also been found in nests of Darwin's ants indicating they have a broader diet than just carbohydrates (Keall and Somerfield 1980). Numerous reports from residents in both Argentine and Darwin's ants infested zones have seen these ants feeding from various fruits (Ward et al. 2010; Pers. Obs.). Argentine ants have also been found on a variety of horticultural crops (Lester et al. 2003). Both species have also been found tending scale insects and protecting them from predation which can increase damage to crops (Lester et al. 2003; Harris 2002; Taylor 1959).

In this thesis my experiments aim to expand on current literature by investigating spatially separated field populations of ants, providing both carbohydrates and proteins in a liquid form, and by investigating a previously little studied species, the Darwin's ant. I also investigated toxic bait efficacy of four commercially available baits in Argentine ants and the influence of colony starvation on mortality rate.

\section{Research Aims}

These experiments were carried out to determine temporal variation in Argentine and Darwin's ants toxic bait, carbohydrate and protein preference. I also tested the efficacy of four different toxic baits in laboratory colonies of Argentine ants. My study sites were at different localities around the Nelson-Tasman region where there are extensive infestations of both ant species.

Initially in Chapter 2 I investigated the toxic bait, carbohydrate and protein preference in the Argentine ant (Linepithema humile) and Darwin's ant (Doleromyrma darwiniana). I compared ant abundance on different bait and food sources, with the highest abundance of ants signifying the most 'preferred' source at that time. Abundance was compared between bait and food sources, between ant species and between months.

In Chapter 3 I examined survival rates in laboratory colonies of Argentine ants exposed to four different toxic baits. The aim of this experiment was to compare toxic bait efficacy and the influence of different starvation levels on mortality rate.

In Chapter 4 I relate the food and toxic bait preference findings, to those of the toxicity results. I discuss the significance of my findings and ideas for future research to supplement these experiments. 
Lastly, I have included an appendix of other important experiments conducted during my study. These experiments provide essential knowledge which could be useful for future research.

Please note:

All months noted and examples cited, are referring to Southern Hemisphere timing. Many studies on Argentine ants are carried out in the Northern Hemisphere so the equivalent timing in Southern hemisphere timing was used in the chapters for ease of interpretation.

I have written Chapters 2 and 3 as individual research papers so there is some unavoidable repetition between chapters. 


\section{Chapter 2:}

\section{Toxic bait, carbohydrate and protein preference in the}

Argentine ant (Linepithema humile) and Darwin's ant (Doleromyrma darwiniana) (Hymenoptera: Formicidae) in

\section{New Zealand}

\section{Abstract}

To improve current baiting methods of invasive ant species it is necessary to investigate their seasonal dietary needs and foraging behaviour. I analysed toxic bait, carbohydrate and protein preference in field populations of Argentine (Linepithema humile) and Darwin's ants (Doleromyrma darwiniana) in the Nelson-Tasman region from March 2010-June 2011. Analysis of four commercially available toxic baits revealed that neither ant species showed a significant difference in preference between Xstinguish $^{T M}$, Exterm-an-Ant $\AA$ and Advion $₫$ ant gel year round, but that Advion $\AA$ ant bait arena was consistently the least preferred bait. Argentine ants showed a significant preference for protein compared to carbohydrate during December and January. Carbohydrate uptake however did not differ significantly compared to protein uptake over the year. For Darwin's ants there was a significantly higher number of ants on carbohydrate food groups compared to the control, but there was no significant preference for protein. Combining the knowledge gained from the toxic bait and food preference experiments, it is recommended that a strategy for future baiting could involve using Xstinguish ${ }^{\mathrm{TM}}$ in spring and summer time when Argentine ants are undergoing reproduction. Darwin's ants showed a significant preference for

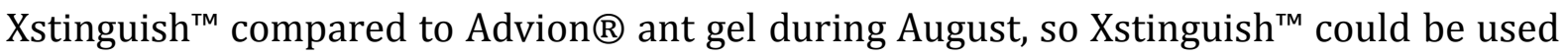
then to see if it reduces ant numbers. Although I observed distinct preferences for carbohydrates and protein at different times of the year, the toxic baits Xstinguish ${ }^{\mathrm{TM}}$, Exterm-an-Ant $\AA$ and Advion $\AA$ ant gel were all highly attractive year round. These results suggest that despite differences between bait formulations, these baits all contain attractive carbohydrate and/or protein sources so that they are consistently appealing regardless of ants' food preferences. 


\section{Keywords}

Argentine ant; Linepithema humile; Darwin's ant; Doleromyrma darwiniana; protein; carbohydrate; seasonal preference; bait preference; toxic bait; control; management; New Zealand

\section{Introduction}

The ability to control invasive ant infestations is largely limited by bait efficacy, bait uptake and the cost of baiting. An effective bait should be palatable and consistently attractive, contain a low toxin level and have a relatively long and stable field life (Stanley 2004). A low toxin level is fundamental to ensure the bait is not repellent and that it will persist in a colony long enough to reach the queens and larvae. To improve control options temporal variation in food preference needs to be further investigated so we can identify with more accuracy when ants will be foraging for one food source over another. With this knowledge, combined with toxic bait preference, we can improve future bait formulations and timing of bait application.

In New Zealand both Argentine and Darwin's ant species are regarded as pests (Don 2007). On a global scale Argentine ants are considered to be one of the most invasive pest species in the world (Wild 2004; Vega and Rust 2001; Harris 2002). Darwin's ants are native to Australia, but they are not considered a pest species there as they often nest in the open country where urbanization is low (Keall 1979).

The Argentine ants' diet predominantly consists of liquid foods such as honeydew and nectar, with additions of protein sources such as insects (Markin 1970a; Vega and Rust 2001; Harris 2002; Abril et al. 2007; Rust et al. 2000). Darwin's ants have a similar preference for carbohydrates such as honeydew and have been observed feeding on prey (Taylor 1959; Keall 1979; Pers. Obs.). Studies have found that Argentine ants' protein and carbohydrate uptake is strongly linked to the reproductive phase of a colony (Abril et al. 2007; Rust et al. 2000). Argentine ants' preference for protein sources has often been observed to increase in the spring months (Abril et al. 2007; Rust et al. 2000; Toft 2010). Argentine ants have been found carrying honeydew and nectar up to $99 \%$ of the time in a field population suggesting a frequent preference for liquid carbohydrates (Markin 1970a), or a ready supply of honeydew. 
Bait efficacy in the Argentine ant has been well documented, while the Darwin's ant has fewer published articles available (Shattuck 1999). Stanley (2004) summarized previous research on the efficacy of commercially available baits and suggested that Xstinguish $^{\mathrm{TM}}$ bait may be the best currently available choice in New Zealand for control of Argentine ants. Other research has determined boric acid and fipronil (active toxin in Xstinguish $^{\mathrm{TM}}$ ) as being an effective and attractive source for controlling Argentine ants (Hooper-Bui and Rust 2000; Vega and Rust 2001). A laboratory comparison of baits in Argentine ant colonies revealed that Xstinguish ${ }^{\mathrm{TM}}$ and Advion ${ }^{\circledR}$ ant bait arenas provided a similar mortality rate (possibly due to both baits containing a protein source which would then reach the queens and larvae more effectively) (Toft and Rees 2009). Comparison of the attractiveness of liquid vs. gel baits in Argentine ants resulted in a higher number of worker ants feeding on gel baits, but considerably more liquid bait was consumed (Silverman and Roulston 2001). My goal was to compare the temporal variation in preference of Xstinguish ${ }^{\mathrm{TM}}$, Exterm-an-Ant ${ }^{\circledR}$, Advion $\AA$ ant gel and Advion $\AA$

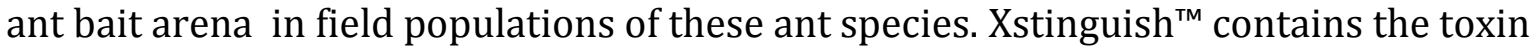
fipronil and egg (protein) and sucrose (carbohydrate) (Stanley 2004). Exterm-an-Ant® contains $8 \%$ boric acid and $5.6 \%$ sodium borate and a sweet carbohydrate solution (Stanley 2004). Advion $\AA$ ant gel is a carbohydrate bait, Advion $®$ ant bait arena contains both a protein and carbohydrate food source, and both baits contain the toxin indoxacarb.

My research differs from above studies as I will be investigating spatially separated field populations of ants, providing both carbohydrates and proteins in a liquid form, and by investigating a previously little studied species, the Darwin's ant. My overall aims are to determine if these ant species show a monthly or seasonal variation in toxic bait, carbohydrate and protein preference. I finish by discussing the importance of carbohydrates and protein for invasive ant species. 


\section{Materials and methods}

\section{Study site}

Field experiments were carried out from March 2010 - June 2011 at 40 different sites

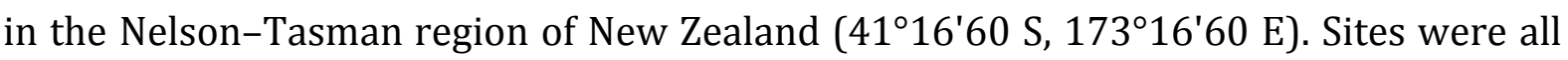
residential ranging from eastern coastal sites at Tasman (near Motueka), Stoke, Richmond and Nelson and also western coastal sites in Wakapuaka. Each ant species had a total of 20 different sites; 10 sites were used for the toxic bait experiments and 10 sites were used for the food preference tests. Sites ranged from being a minimum of $100 \mathrm{~m}$ to several kilometres apart. Due to the proximity of experimental sites, there are between 1-8 experimental sites within each location (black or white circle) shown on the map (Figure 1). The Nelson-Tasman region experiences warm, dry summers and mild winters with frequent morning frosts making this region an optimal habitat for these ant species establishment (NIWA 2011).

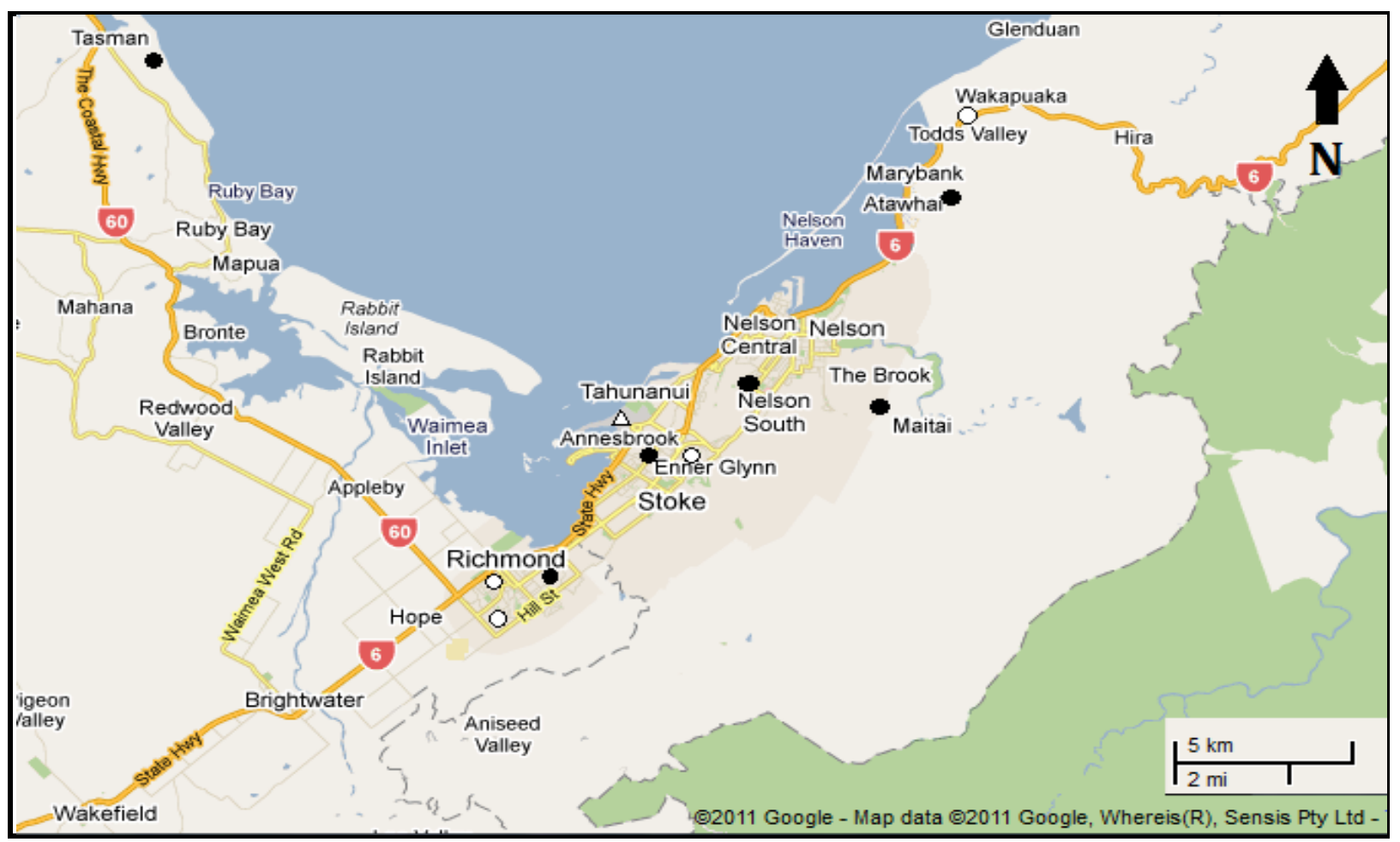

Figure 1.1. Experimental locations in the Nelson-Tasman region. $\bigcirc$ Argentine ant sites. Darwin's ant sites. $\triangle$ NIWA Weather station used in the data collection. Map adapted from Google Maps. 


\section{Field methods}

Two experiments aimed to determine the preference of ants among four different toxic baits and seven different food types by counting the number of ants feeding from them. The four commercially available toxic baits tested were Xstinguish ${ }^{\mathrm{TM}}$, Exterm-anAnt ${ }^{\circledR}$, Advion ${ }^{\circledR}$ ant gel and Advion $\AA$ ant bait arena (Advion ${ }^{\circledR}$ ant bait arenas were withdrawn for sale by DuPont (New Zealand) Ltd. in 2010). Xstinguish ${ }^{\mathrm{TM}}$ is a protein and carbohydrate mixed bait with $0.01 \%$ fipronil (Toft and Rees 2009).Exterm-an-Ant ${ }^{\circ}$ is a liquid carbohydrate bait and its active toxin is boric acid. Advion ${ }^{\circledR}$ ant gel is a carbohydrate based white gel which contains the active toxin indoxacarb at a concentration of $0.5 \mathrm{~g} / 1 \mathrm{~kg}$. Advion $\AA$ ant bait arena is a carbohydrate and protein brown paste with the toxin indoxacarb at a level of $1 \mathrm{~g} / \mathrm{kg}$.

Three different concentrations of a carbohydrate and a protein source and one control were tested in the food preference experiments. The carbohydrate source was sucrose in a powder form and the protein source was casein powder. Sucrose was chosen as it is readily accepted by both ant species (see appendix). Casein is a protein derived from cows' milk and it was chosen as it is readily soluble in water and has been frequently used in other studies on ants (Kay 2002; Kay 2004). The concentrations of carbohydrate and protein were: $5 \%, 10 \%$ and $30 \%$ sucrose: water concentrations and $5 \%, 10 \%$ and $15 \%$ casein: water concentrations and one water only control. The water only control was to ensure the ants aren't being drawn to the liquid rather than the actual food source. Concentrations were measured by combining $150 \mathrm{mls}$ of distilled water with the above concentrations of sucrose or casein powder.

Each of the four toxic baits were placed $\sim 5 \mathrm{~cm}$ apart on a ceramic tile $(20 \mathrm{~cm} \times 20 \mathrm{~cm})$ in approximately equal amounts of $1 \mathrm{~cm}^{3}$ (Fig. 1.2a). The seven different liquid foods were saturated onto a cotton wool square $(\sim 2 \mathrm{~cm} \times 2 \mathrm{~cm})$ and placed on a tile. Each food was randomly placed onto the tile each testing time and its identification code was written underneath it (Fig. 1.2b). In both experiments plastic ice cream containers with access slits ( $\sim 15 \mathrm{~cm}$ length $\times 2 \mathrm{~cm}$ width) were cut into all four sides and placed over the tile to stop interference from other animals and reduce the rate of desiccation. Another tile was placed on top of the container to keep it in place. Tiles were only placed where ants were seen trailing or nesting. 
During winter, ants were rarely active in the morning and were never observed foraging below temperatures of five ${ }^{\circ} \mathrm{C}$ in studies conducted by Markin (1970a) and Abril et al. (2007). At my study sites Argentine ants were occasionally observed trailing at $10{ }^{\circ} \mathrm{C}$ but they were not actively foraging as they would explore the food tile, but not feed (Pers. Obs.). Therefore the best time during winter to conduct experiments was between $11 \mathrm{am}-3 \mathrm{pm}$ when higher numbers of ants were active. Optimal foraging time has been noted in similar studies to be when temperatures are between 15-30 degrees (Rust et al. 2000). During summer time ants were far more active due to warmer temperatures (Harris 2002; Pers. Obs.) and experiments were conducted in the early morning as desiccation of liquid foods became an issue later in the day if they were exposed in the field for long periods.

Between 45-60 minutes after a tile was placed at a site, a photograph was taken of ant numbers on the tile. In the toxic bait experiments a total of two photographs were taken approximately an hour apart. In the food experiments a total of three photographs were taken an hour apart. The toxic bait tiles were only left in the field for a maximum of three hours, as recruitment to baits may be affected after this time (Pers. Comm. R. Toft). Field studies on bait preference noted that Xstinguish is a fast acting bait and dries quickly so uptake may be affected after a few hours if ants detect the bait is toxic or if it is unpalatable (Toft 2010). Ant numbers were later counted from each photograph and the numbers were recorded. Ants were counted in a photograph by counting each ant that was directly touching the bait or food. Preference was determined based on differential recruitment numbers to each bait and food source (Kay 2004).

Soil temperature data at each site was also recorded at the same time as photographs. Soil temperature was measured with a digital soil thermometer at a soil depth of $\sim 5$ $8 \mathrm{~cm}$. Daily rainfall, maximum and minimum air temperatures and hourly humidity were also recorded on experimental days (Cliflo 2011). (Climate data was recorded at NIWA weather station G13222: location noted in Figure 1: 410302' 1730219'). 

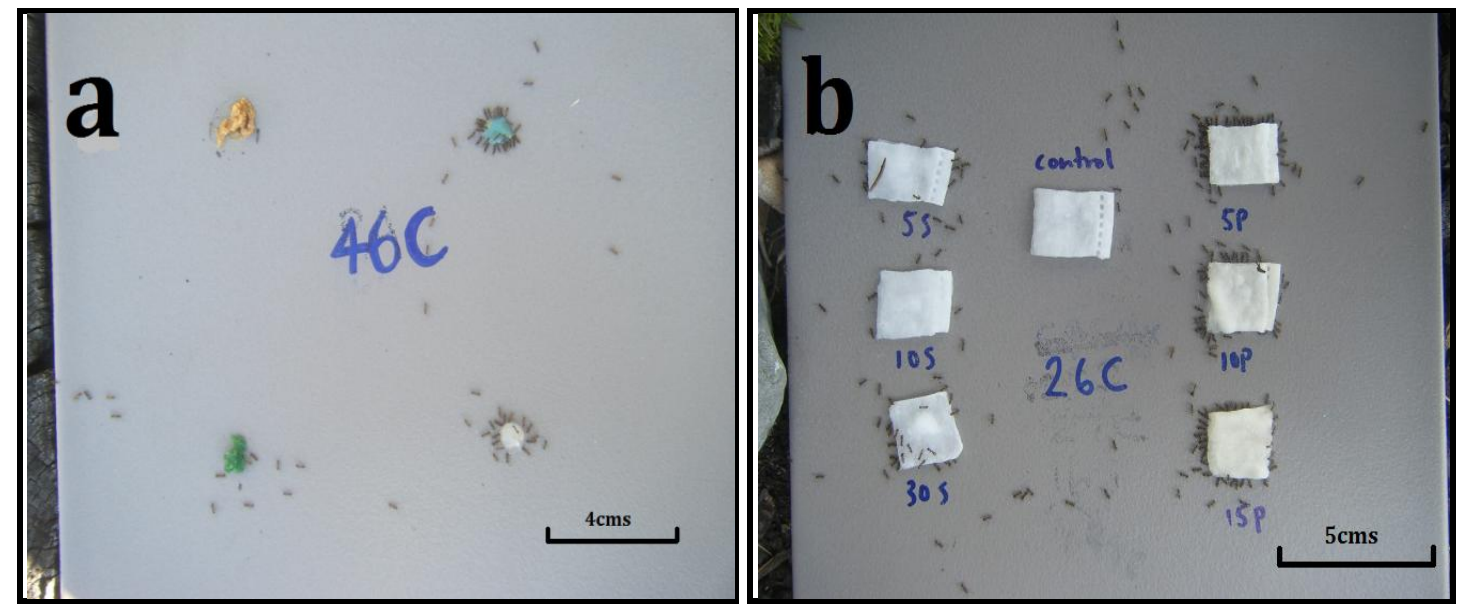

Figure 1.2a. An example of a ceramic tile with four different toxic baits. Clockwise from top left: Advion ${ }^{\circledR}$ ant bait arena , Exterm-an-Ant ${ }^{\circledR}$, Advion ${ }^{\circledR}$ ant gel, Xstinguish ${ }^{\text {TM }}$ ' $46 C^{\prime}$ ' is the site code. 1.2 b. An example of a ceramic tile with six different food sources and a water control. Codes are $5 \mathrm{P}=5 \%$ protein, $10 \mathrm{P}=10 \%$ protein, $15 \mathrm{P}=15 \%$ protein, $5 \mathrm{~S}=5 \%$ sucrose, $10 \mathrm{~S}=10 \%$ sucrose and $30 \mathrm{~S}=30 \%$ sucrose. ' $26 \mathrm{C}$ ' is the site code.

\section{Statistical analysis}

All statistical analyses were performed with PASW Statistics 18 (SPSS Inc., Chicago 2009). To analyse count data a Poisson model was the most suitable. Sample variance was higher than would be expected for a Poisson distribution so a Generalized Estimated Equations method of fitting the data was used. A Generalized Estimated Equations model was also best suited for this data as it incorporates the within subject variable 'time'. Time, soil temperature and humidity all consisted of two levels and were repeated within each site and month observation. An AR(1) covariance structure was used to model the covariance between the two time points.

The dependent variable in both toxic bait and food preference tests was the number of ants. Factors were ant species (two species), month (12 months), time (two or three time frames) and bait type (four baits) or food type (seven levels). The factors bait type and food type were never used in the same model. The two covariates were soil temperature and humidity. Time was used as the within subject (nest) variable as the dependent variable was the number of ants at different time frames. In the toxic bait preference experiments the number of ants was recorded at times one and two hours after the tile had been placed. For the food preference experiments the number of ants 
was recorded at times one, two and three hours after the tile was placed. The factors May (coded month 12), Advion® ant bait arena (coded bait type 4) and control (coded food 7) were used as the baseline levels for the factors in the Poisson model as these had the lowest ant numbers for both species.

Initially I used a generalized estimating equations (Poisson) model on each individual species to predict if there was any significant difference between the number of ants by time (two time frames for toxic bait experiment or three time frames for food preference experiment). I also compared ant numbers between time, bait type or food type, month, soil temperature and humidity for each ant species.

Secondly, I conducted generalized linear (Poisson) models for the toxic bait experiments on the second hour data only. This was because there were many zero data values in the first hour, but not in the second hour. Also the generalized estimating equations model determined that there was a significant difference between the two hours of time and the second hour had more ants for both species. Therefore to ensure a model of better fit and minimise the amount of zero values, only the second hour of data was used in this model.

Similarly in the food preference experiments I conducted generalized estimating equations models first to determine if time was a significant influence on ant numbers. There was also a substantial number of zero values for both species in the first two hours. Therefore I used the third hour of data to carry out the generalized linear (Poisson) model analysis. I conducted a generalized linear (Poisson) model on Argentine ants plus all main effects and a month and bait type interaction. Darwin's ants food preference data contained numerous zero counts so it was not possible to investigate the possibility of an interaction effect between month and food type, due to singularity problems. Therefore to produce a model of better fit which would allow an interaction term to be added, data from different months were grouped together. These were month group 1 (May-October) and month group 2 (November-April). These months were grouped together based on their similar number of ant counts. For example May-October had higher numbers of ants, while November-April had lower numbers of ants. 


\section{Results}

\section{Toxic bait preference}

The number of ants were generally highest in the summer months from DecemberFebruary. The three baits Xstinguish ${ }^{\mathrm{T} M}$, Exterm-an-Ant ${ }^{\circledR}$ and Advion ${ }^{\circledR}$ ant gel had similar numbers of ants throughout the year, but Advion $\AA$ ant bait arena typically had fewer ants at all times (Figure 1.3 and 1.4).

The generalized estimating equations model showed there was a significant difference in ant numbers between the first and second hour after tiles were placed. Argentine ants had an expected 29.9\% fewer ants at the first hour than at the second hour $(\mathrm{p}<0.05)$. Similarly Darwin's ants had a significant difference in ant numbers of 59.3\% fewer ants to be expected at the first hour than at the second hour $(\mathrm{p}<0.05)$. Due to the significant difference in time, a generalized linear model was carried out on the second hour of data for each individual species. I wanted to determine what the most preferred bait or food source was when foraging numbers were at their highest, so the second hour of data was analysed for the toxic bait experiments as this would give a better indication of what the majority of ants preferred.

The generalized linear model showed that for both ant species the baits Xstinguish ${ }^{\mathrm{TM}}$, Exterm-an-Ant ${ }^{\circledR}$ and Advion $\AA$ ant gel are overall statistically different to Advion $®$ ant bait arena $(\mathrm{p}<0.05)$, and are predicted to have more ants (Table 1.1 and 1.2). Both tables (1.1 and 1.2) are only displaying the significant effects where $p<0.033$ or where 95\% confidence intervals do not overlap.

For Argentine ants, the $95 \%$ confidence intervals for Xstinguish ${ }^{\mathrm{TM}}$, Exterm-an-Ant ${ }^{\circledR}$ and Advion $®$ ant gel overlapped every month, indicating that the preference for these three baits are not statistically different from each other, just from Advion ${ }^{\circledR}$ ant bait arena . Xstinguish $^{\mathrm{TM}}$ and Exterm-an-Ant ${ }^{\circledR}$ were significantly different compared to Advion $\AA$ ant bait arena $(p<0.05)$ during July, August, September, November, December, January, February and March (Table 1.1). Advion ${ }^{\circledR}$ ant gel was statistically significant compared to Advion ${ }^{\circledR}$ ant bait arena $(\mathrm{p}<0.05)$ in June, August, November, December and February (Table 1.1). 
For Darwin's ants, the numbers of ants feeding from Xstinguish ${ }^{\mathrm{TM}}$ was statistically different $(\mathrm{p}<0.05)$ from Advion $\AA$ ant bait arena during June, August, November, December and April. Exterm-an-Ant $\AA$ was statistically different $(\mathrm{p}<0.05)$ to Advion $®$ ant bait arena during June, July, December and January. Advion ${ }^{\circledR}$ ant gel was statistically different $(\mathrm{p}<0.05)$ to Advion ${ }^{\circledR}$ ant bait arena during June, July, December, January and February (Table 1.2). There was only one significant difference in bait preference between the three most preferred baits which was between Xstinguish ${ }^{\text {TM }}$ and Advion ${ }^{\circledR}$ ant gel in August whereby Xstinguish ${ }^{\text {TM }}$ was the most preferred $(95 \% \mathrm{CI}$, 0.504-1.852. $\mathrm{p}<0.05)$ over Advion $®$ ant gel (95\% CI, -0.896- 0.433. p= 0.495).

For both ant species, soil temperature and humidity had a significant effect on ant numbers $(\mathrm{p}<0.05)$. For every one degree increase in soil temperature there would be an expected 0.101 more ants for Argentine ants, and an increase of 0.129 ants for Darwin's ants. An increase in humidity of $1 \%$ is expected to reduce Argentine ant numbers by 0.007 ants and increase Darwin's ants by 0.004 ants (Table 1.1 and 2). 


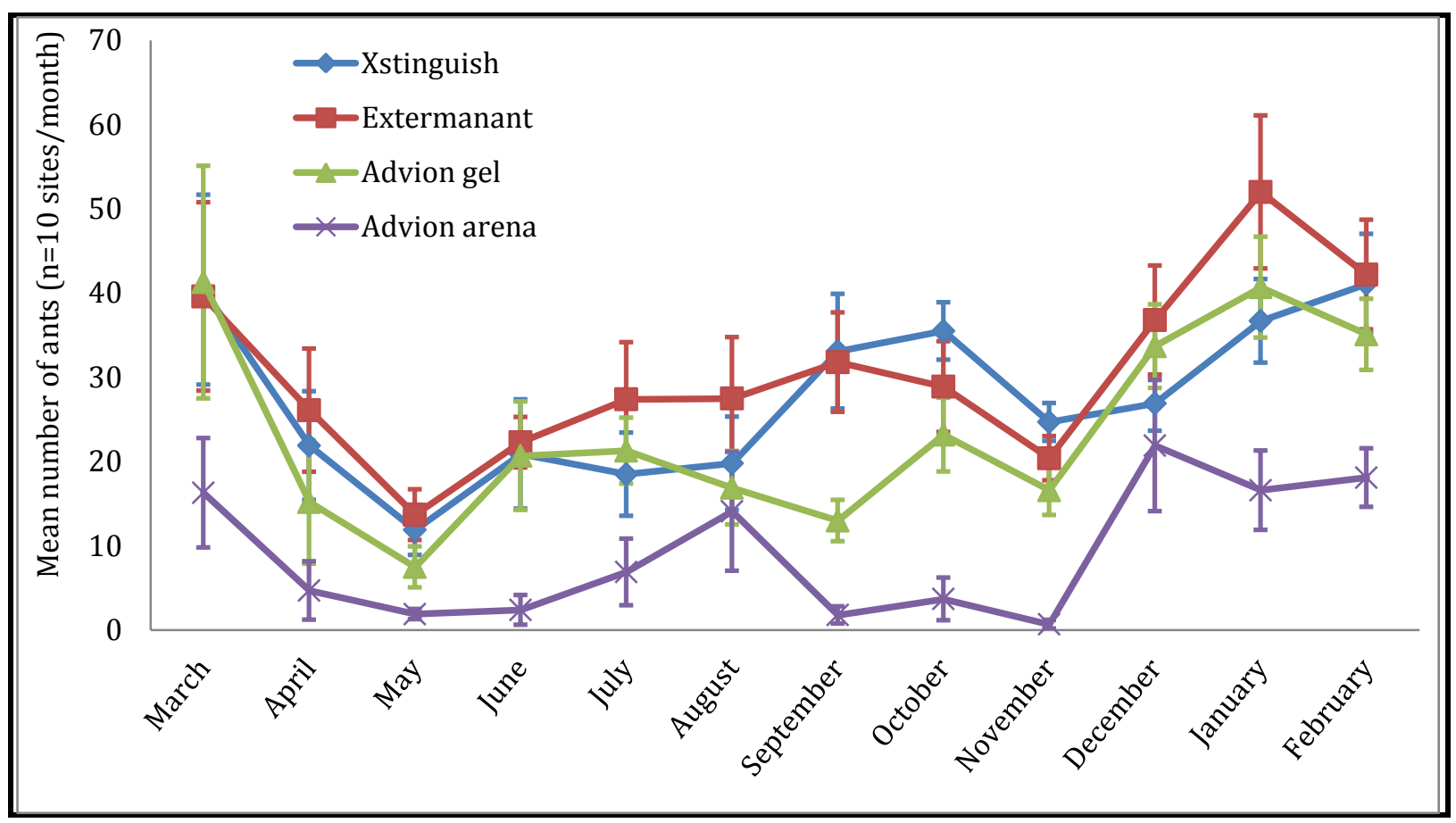

Figure 1.3. Mean number of Argentine ants at the second hour of observations (+-SE) feeding on different toxic baits per month.

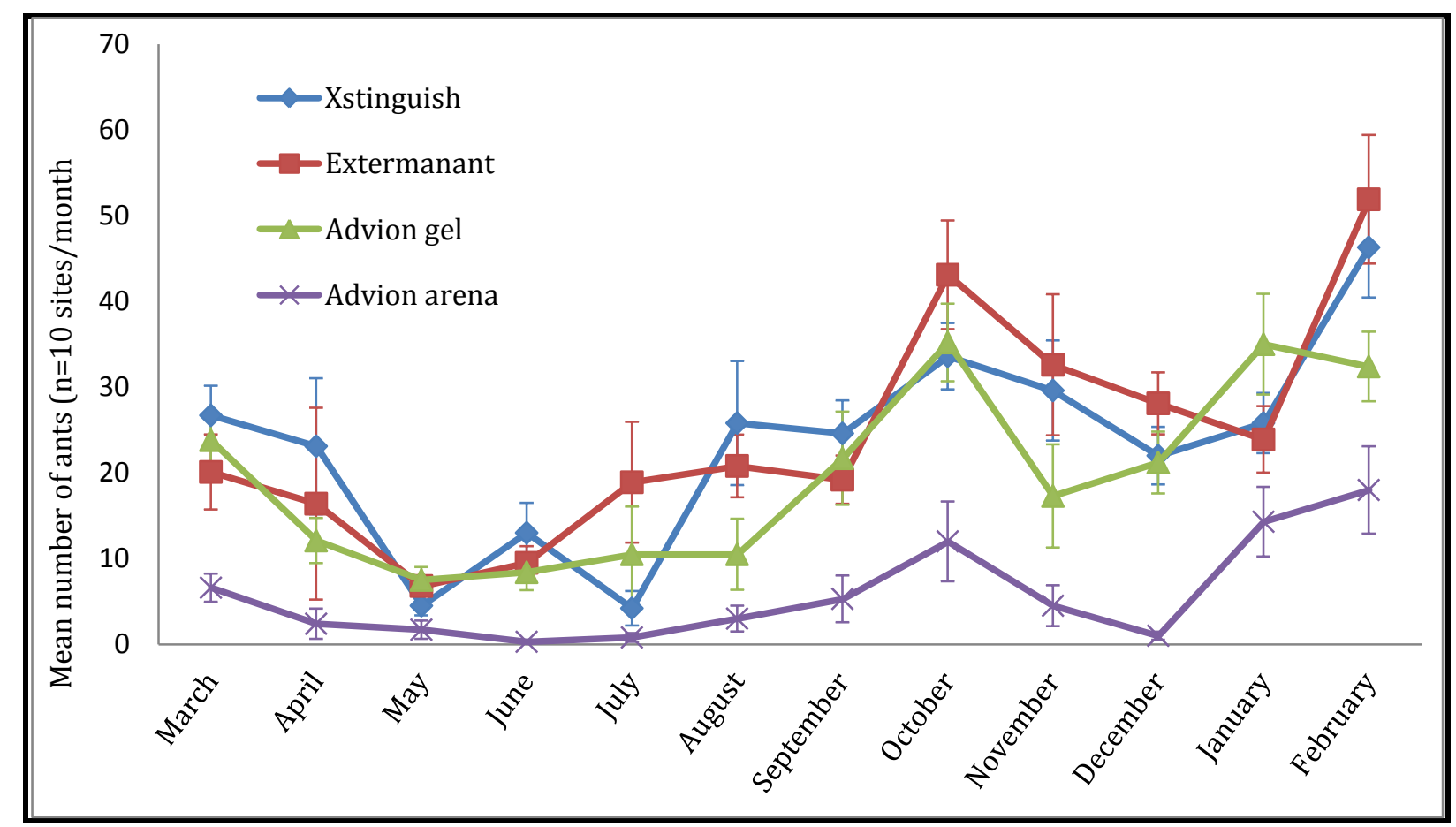

Figure 1.4. Mean number of Darwin's ants at the second hour of observations (+-SE) feeding on different toxic baits per month. 


\begin{tabular}{|c|c|c|c|c|c|c|c|}
\hline \multirow[t]{2}{*}{ Parameter } & \multirow[b]{2}{*}{ B } & \multirow[b]{2}{*}{$\begin{array}{l}\text { Std. } \\
\text { Error }\end{array}$} & \multicolumn{2}{|c|}{\begin{tabular}{|c} 
95\% Wald Confidence \\
Interval \\
\end{tabular}} & \multicolumn{3}{|c|}{ Hypothesis Test } \\
\hline & & & Lower & Upper & $\begin{array}{c}\text { Wald Chi- } \\
\text { Square }\end{array}$ & Df & Sig. \\
\hline (Intercept) & -.156 & .3035 & -.751 & .439 & .264 & 1 & .607 \\
\hline June & .367 & .3079 & -.236 & .971 & 1.423 & 1 & .233 \\
\hline July & .998 & .2601 & .488 & 1.507 & 14.706 & 1 & .000 \\
\hline August & 1.649 & .2471 & 1.165 & 2.134 & 44.560 & 1 & .000 \\
\hline September & -.273 & .3379 & -.935 & .390 & .652 & 1 & .420 \\
\hline October & .160 & .2924 & -.413 & .733 & .299 & 1 & .584 \\
\hline November & -1.611 & .4487 & -2.490 & -.732 & 12.892 & 1 & .000 \\
\hline December & 1.647 & .2643 & 1.130 & 2.165 & 38.865 & 1 & .000 \\
\hline January & 1.444 & .2544 & .945 & 1.943 & 32.218 & 1 & .000 \\
\hline February & 1.425 & .2682 & .899 & 1.951 & 28.226 & 1 & .000 \\
\hline March & 1.108 & .2582 & .602 & 1.615 & 18.430 & 1 & .000 \\
\hline April & .780 & .2728 & .245 & 1.315 & 8.173 & 1 & .004 \\
\hline May & $0^{\mathrm{a}}$ & . & . & . & . & . & . \\
\hline Xstinguish & 1.835 & .2471 & 1.350 & 2.319 & 55.150 & 1 & .000 \\
\hline Exterm-an-Ant ${ }^{\circledR}$ & 1.976 & .2448 & 1.496 & 2.455 & 65.121 & 1 & .000 \\
\hline Advion $\circledR$ ant gel & 1.373 & .2568 & .870 & 1.876 & 28.580 & 1 & .000 \\
\hline Advion arena & $0^{\mathrm{a}}$ & . & . & . & . & . & . \\
\hline Soil temperature & .101 & .0100 & .081 & .120 & 102.788 & 1 & .000 \\
\hline Humidity & -.007 & .0019 & -.010 & -.003 & 12.100 & 1 & .001 \\
\hline June*Advion ${ }^{\circledR}$ ant gel & .782 & .3354 & .124 & 1.439 & 5.432 & 1 & .020 \\
\hline June*Advion arena & $0^{\mathrm{a}}$ & . & . & . & . & . & . \\
\hline July*Xstinguish & -.848 & .2845 & -1.406 & -.291 & 8.894 & 1 & .003 \\
\hline July*Exterm-an-Ant ${ }^{\circledR}$ & -.597 & .2794 & -1.144 & -.049 & 4.558 & 1 & .033 \\
\hline July*Advion arena & $0^{a}$ & . & . & . & . & . & . \\
\hline August*Xstinguish & -1.495 & .2705 & -2.025 & -.965 & 30.550 & 1 & .000 \\
\hline August*Exterm-an-Ant ${ }^{\circledR}$ & -1.308 & .2658 & -1.829 & -.787 & 24.195 & 1 & .000 \\
\hline August*Advion ${ }^{\circledR}$ ant gel & -1.192 & .2810 & -1.743 & -.641 & 17.989 & 1 & .000 \\
\hline August*Advion arena & $0^{\mathrm{a}}$ & . & . & . & . & . & . \\
\hline September*Xstinguish & 1.077 & .3458 & .399 & 1.755 & 9.699 & 1 & .002 \\
\hline September*Exterm-an-Ant ${ }^{\circledR}$ & .896 & .3444 & .221 & 1.571 & 6.769 & 1 & .009 \\
\hline September*Advion arena & $0^{\text {a }}$ & |. & & & & & . \\
\hline
\end{tabular}

Table 1.1. Argentine ants generalized linear model of toxic bait preference. Dependent variable was number of ants. Parameters tested were: month, bait type, soil temperature, humidity, month*bait type. Only data from the second hour was analysed. $0^{a}$ : Set to zero because this parameter is the baseline. 


\begin{tabular}{|c|c|c|c|c|c|c|c|}
\hline November*Xstinguish & 1.729 & 4560 & .835 & 2.623 & 14.373 & 1 & .000 \\
\hline November*Exterm-an-Ant $®$ & 1.397 & .4557 & .503 & 2.290 & 9.392 & 1 & .002 \\
\hline November*Advion $®$ ant gel & 1.793 & .4635 & .885 & 2.702 & 14.964 & 1 & .000 \\
\hline November*Advion arena & $0^{\mathrm{a}}$ & & . & . & . & . & . \\
\hline December*Xstinguish & -1.629 & .2633 & -2.145 & -1.113 & 38.284 & 1 & .000 \\
\hline December*Exterm-an-Ant ${ }^{\circledR}$ & -1.457 & .2593 & -1.965 & -.948 & 31.563 & 1 & .000 \\
\hline December*Advion ${ }^{\circledR}$ ant gel & -.942 & .2711 & -1.473 & -.411 & 12.074 & 1 & .001 \\
\hline December*Advion arena & $0^{\mathrm{a}}$ & & . & . & . & . & \\
\hline January*Xstinguish & -1.049 & .2642 & -1.567 & -.531 & 15.760 & 1 & .000 \\
\hline January*Exterm-an-Ant ${ }^{\circledR}$ & -.841 & .2605 & -1.352 & -.330 & 10.422 & 1 & .001 \\
\hline January*Advion arena & $0^{\mathrm{a}}$ & & . & . & . & $\cdot$ & . \\
\hline February*Xstinguish & -.982 & .2628 & -1.497 & -.467 & 13.961 & 1 & .000 \\
\hline February*Exterm-an-Ant ${ }^{*}$ & -1.097 & .2606 & -1.607 & -.586 & 17.703 & 1 & .000 \\
\hline February*Advion $®$ ant gel & -.711 & .2727 & -1.245 & -.176 & 6.796 & 1 & .009 \\
\hline February*Advion arena & $0^{\mathrm{a}}$ & & . & . & . & $\cdot$ & . \\
\hline March*Xstinguish & -.927 & .2639 & -1.444 & -.410 & 12.339 & 1 & .000 \\
\hline March*Exterm-an-Ant ${ }^{\circledR}$ & -1.088 & .2619 & -1.601 & -.575 & 17.254 & 1 & .000 \\
\hline March*Advion arena & $0^{\mathrm{a}}$ & & . & . & . & . & . \\
\hline
\end{tabular}

Table 1.1. continued. Argentine ants generalized linear model of toxic bait preference. Dependent variable was number of ants. Parameters tested were: month, bait type, soil temperature, humidity, month*bait type. Only data from the second hour was analysed. $0^{\mathrm{a}}$ : Set to zero because this parameter is the baseline. 


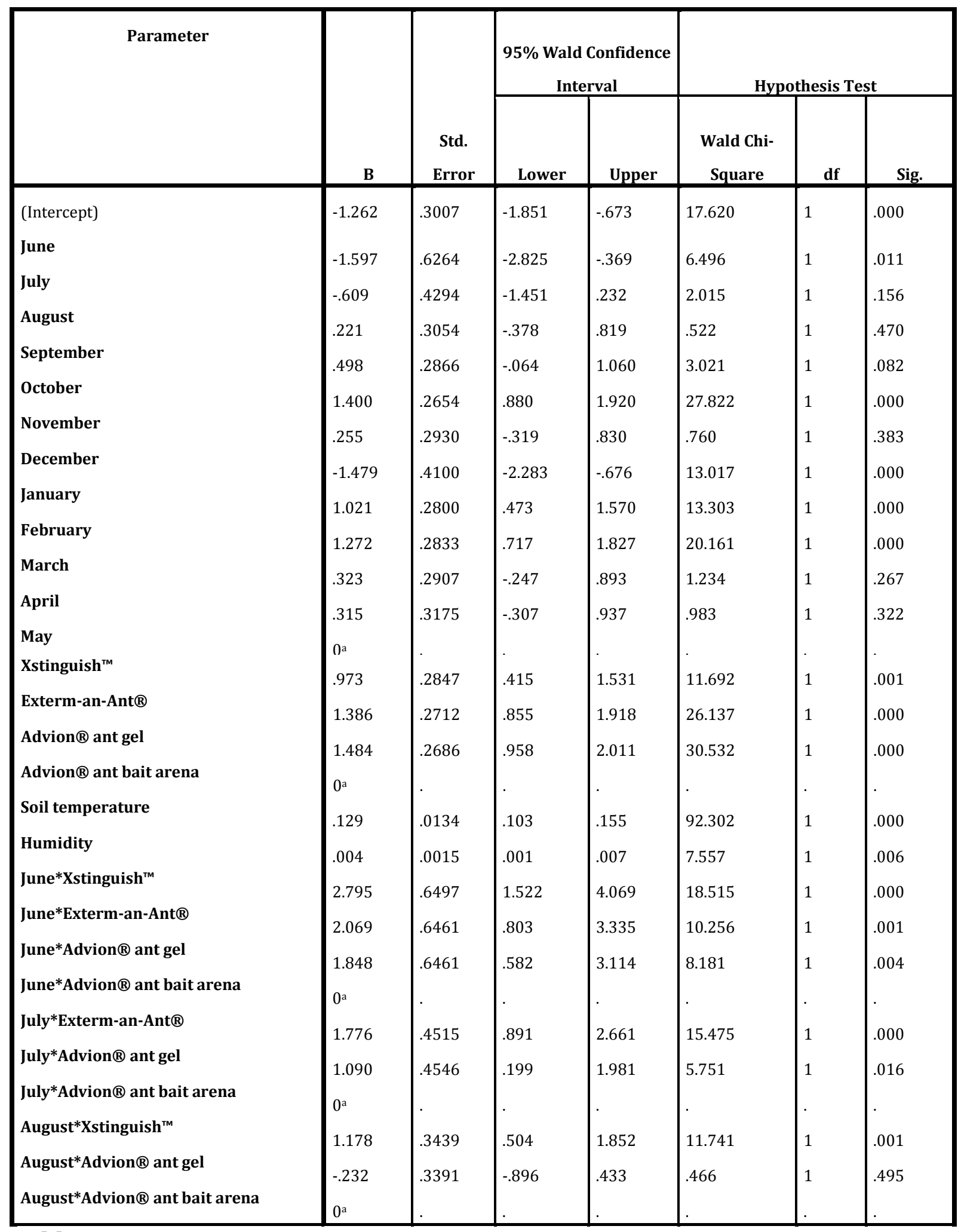

Table 1.2. Darwin's ants generalized linear model of toxic bait preference experiment. Dependent variable was number of ants. Parameters tested were: month, bait type, soil temperature, humidity, month*bait type. Only data from the second hour was analysed. $0^{\text {a }}$ : Set to zero because this parameter is the baseline. 


\begin{tabular}{|c|c|c|c|c|c|c|c|}
\hline & & & & \\
\hline November*Xstinguish $^{\mathrm{TM}}$ & 910 & .3266 & .270 & 1.550 & 7.769 & 1 & .005 \\
\hline November*Advion $\AA$ ant bait arena & $0^{\mathrm{a}}$ & & & & & . & \\
\hline December*Xstinguish $^{\mathrm{TM}}$ & 2.118 & .4308 & 1.273 & 2.962 & 24.162 & 1 & .000 \\
\hline December*Exterm-an-Ant ${ }^{\circledR}$ & 1.949 & .4208 & 1.125 & 2.774 & 21.461 & 1 & .000 \\
\hline December*Advion ${ }^{\circledR}$ ant gel & 1.570 & .4206 & .745 & 2.394 & 13.931 & 1 & .000 \\
\hline December*Advion ${ }^{\circledR}$ ant bait arena & & & & & & . & \\
\hline January*Exterm-an-Ant ${ }^{\circledR}$ & -.873 & .2910 & -1.443 & -.302 & 8.991 & 1 & .003 \\
\hline January*Advion ${ }^{*}$ ant gel & -.589 & .2864 & -1.150 & -.028 & 4.233 & 1 & .040 \\
\hline January*Advion $®$ ant bait arena & & & & & & . & \\
\hline February*Advion ${ }^{\circledR}$ ant gel & -.896 & .2843 & -1.454 & -.339 & 9.947 & 1 & .002 \\
\hline February*Advion $®$ ant bait arena & & & & & & . & . \\
\hline $\begin{array}{l}\text { April }^{*} \text { Xstinguish } \\
\text { Apri } \\
\text { April*Advion }{ }^{\mathrm{M}} \text { ant bait arena }\end{array}$ & $\begin{array}{l}1.291 \\
0^{\mathrm{a}}\end{array}$ & .3564 & & 1.990 & & 1 & .000 \\
\hline
\end{tabular}

Table 1.2. continued. Darwin's ants generalized linear model of toxic bait preference experiment. Dependent variable was number of ants. Parameters tested were: month, bait type, soil temperature, humidity, month*bait type. Only data from the second hour was analysed. $0^{a}$ : Set to zero because this parameter is the baseline.

\section{Carbohydrate and protein preference}

Different patterns of food preference were observed for each ant species at different times of the year. For Argentine ants, sucrose was highly preferred over much of the year, except over the summer months (December-January), where protein was significantly more preferable. Darwin's ants highly preferred carbohydrates year round, especially during August-October. For both ant species a generalized estimating equations model revealed there was a significant difference in ant numbers between the first, second and third hours $(\mathrm{p}<0.05)$. Both ant species had significantly fewer ants at the first and second hour than at the third hour $(\mathrm{p}<0.05)$.

For Argentine ants, a generalized linear model on the third hour of data showed that overall ant numbers in all food types differed significantly to the control group (Table 1.3). Ant numbers in the $10 \%$ casein and $30 \%$ sucrose food groups differed from each other as the 30\% sucrose group (95\% CI, 3.444-5.719) had a marginally higher expected number of ants than the $10 \%$ casein group (95\% CI, 1.043-3.424). All three of 
the carbohydrates significantly differed in ant numbers compared to the control during August-March whereby there was a higher expected number of ants consuming these foods compared to control. However carbohydrate preference was not significantly higher than protein preference over the year as their confidence intervals overlapped every month (Table 1.3). The 5\% protein group also had significantly higher ant numbers compared to the control during July $(\mathrm{p}=0.033)$ and September $(\mathrm{p}=0.003)$ and the $10 \%$ protein group also had higher numbers compared to the control during July $(\mathrm{p}=0.043)$ (Table 1.3). Protein preference exceeded carbohydrate preference during December and January where confidence intervals did not overlap (Table 1.3). During December there was a higher expected number of ants on the 10\% protein group (95\% CI, -1.094-1.379) compared to all of the carbohydrate groups (5\% sucrose 95\% CI, 3.996- -1.611; $10 \%$ sucrose 95\% CI, -3.577- -1.191; 30\% sucrose 95\% CI, -1.355-1.066). Also there were more ants expected on the 15\% protein group (95\% CI, -1.355-1.066) compared to the $5 \%$ sucrose group (95\% CI, -3.996-1.611). During January $10 \%$ protein (95\% CI, $-0.755-1.718$ ) and 15\% protein (95\% CI, -0.936-1.486) had a higher number of ants than $5 \%$ sucrose (95\% CI, $-3.623-1.241$ ). $10 \%$ protein (95\% CI, $-0.755-1.718$ ) also had higher ant numbers than $30 \%$ sucrose (95\% CI, -3.269-0.898).

A generalized estimating equations model was conducted on the Darwin's ant data. In general there were higher ant numbers in month group 1 (May-October) compared to month group 2 (November-April) ( $b=1.877, \mathrm{p}<0.05)$. This result was clearly evident in mean numbers of Darwin's ants per month (Figure 1.6). The model showed that overall ant numbers were significantly higher in all of the carbohydrate food groups compared to the control $(\mathrm{p}<0.05)$. However the interaction terms between all the carbohydrate groups and month group 1 and 2 were not significant ( $>0.05)$, thus the effect of carbohydrates on the number of ants was not influenced by month group. There was an overall lower number of ants on all of the protein groups compared to the carbohydrate groups, and the protein groups were not statistically different to the control (Table 1.4). Despite this, there were significant interaction terms between the $10 \%$ protein $(\mathrm{p}<0.05$, $b=-1.225)$ and $15 \%$ protein $(p<0.05, b=-1.103)$ groups and month group 1 , which shows that there is a significant decrease in ant numbers compared to the control during month group 1 for these food groups (Table 1.4). 
For both ant species, soil temperature and humidity had a significant effect on ant numbers $(p<0.05)$. For every one degree rise in soil temperature there was an expected increase of 0.094 ants in Argentine ant numbers and an increase of 0.324 ants in Darwin's ant numbers. An increase in humidity by $1 \%$ is expected to reduce Argentine ants by 0.009 ants and reduce Darwin's ants numbers by 0.017 ants (Table 1.3 and 1.4). Both tables (1.3 and 1.4) are only displaying the significant effects where $p<0.043$ or where $95 \%$ confidence intervals do not overlap.

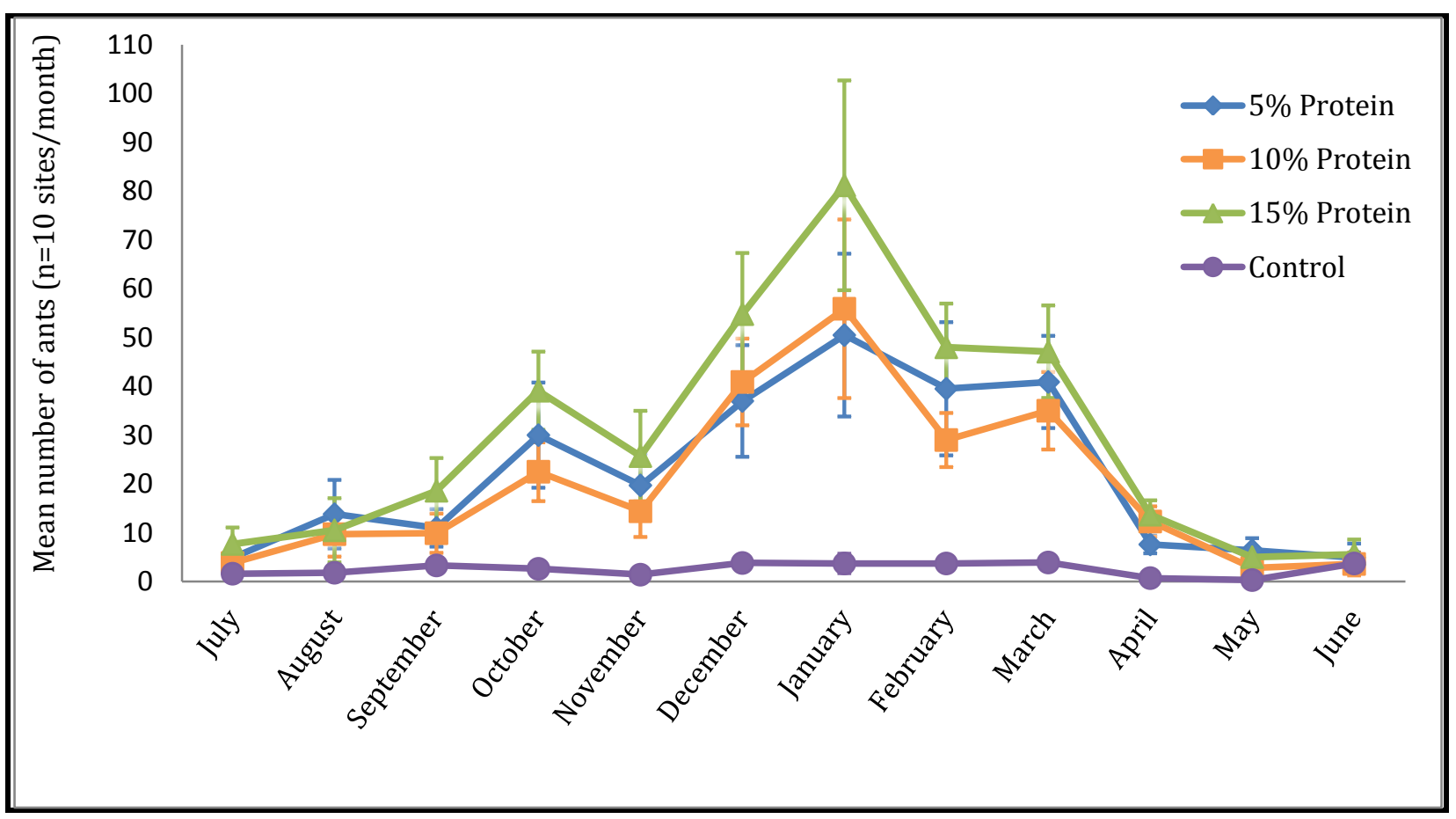

Figure 1.5. Mean number of Argentine ants (+-SE) feeding on different protein: water solutions and a control solution per month. 


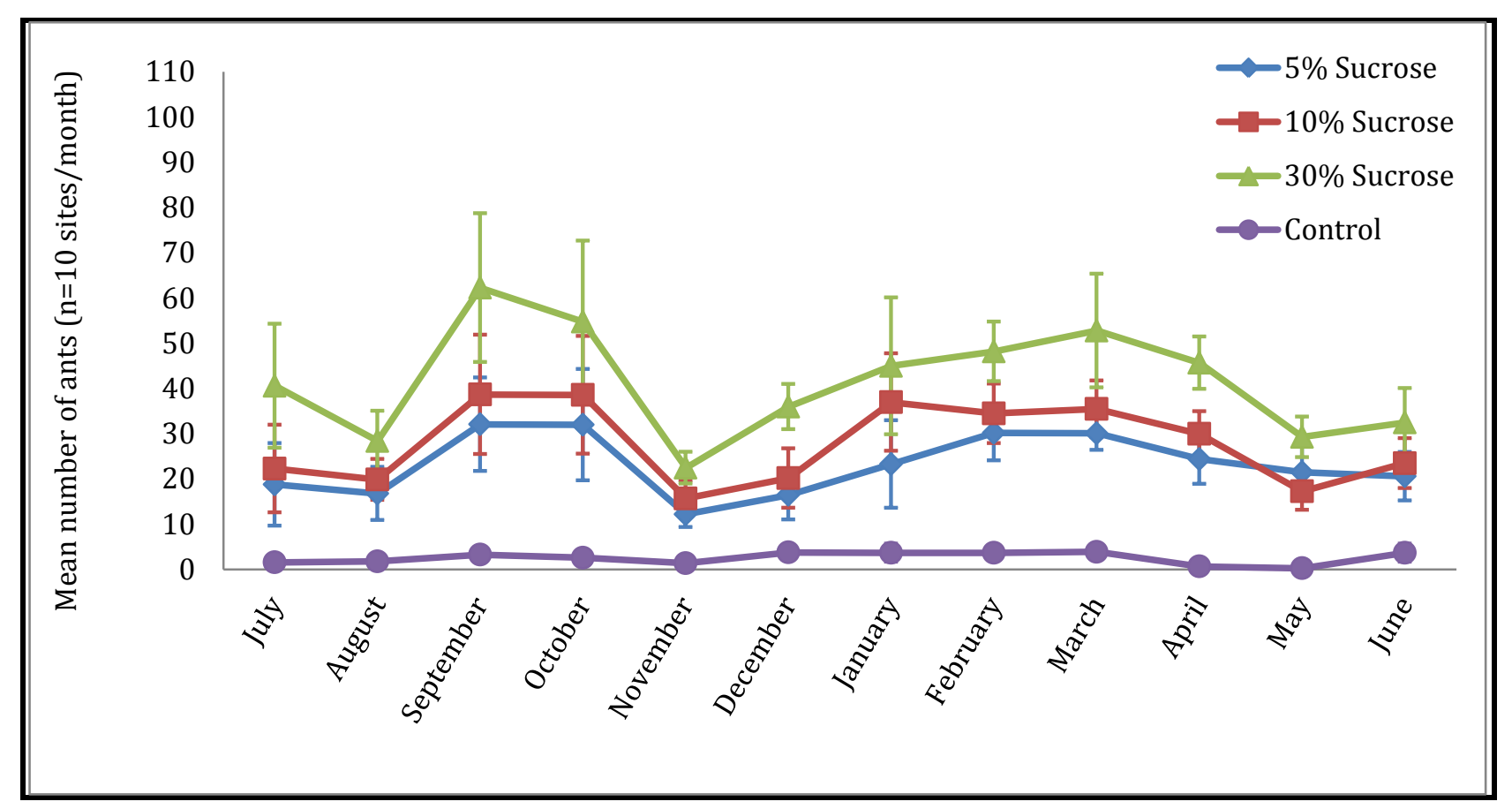

Figure 1.6. Mean number of Argentine ants at the third hour of observations (+-SE) feeding on different sucrose: water solutions and a control solution per month.

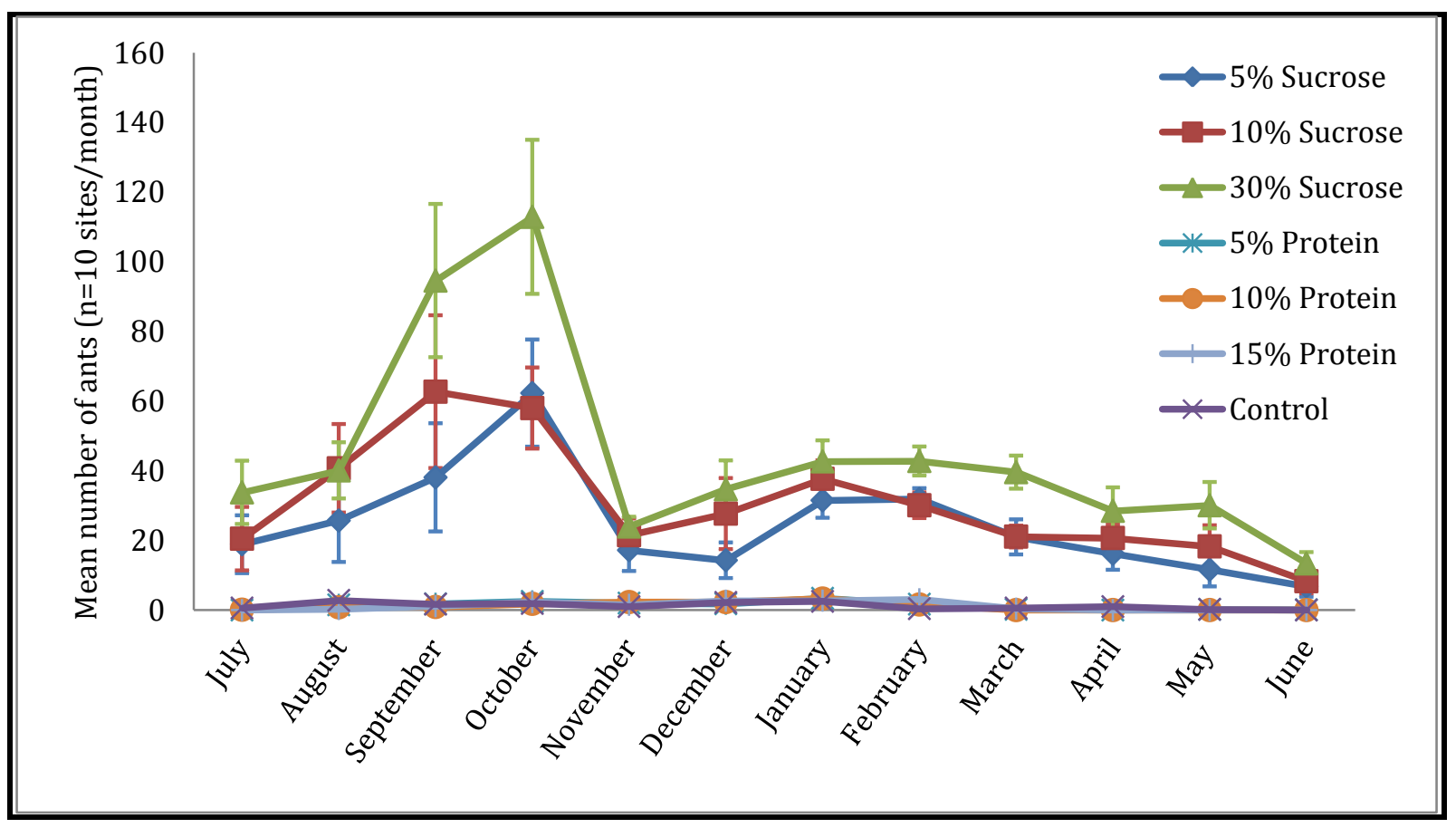

Figure 1.7. Mean number of Darwin's ants at the third hour of observations (+-SE) feeding on different sucrose: water and protein: water solutions and a control solution per month. 


\begin{tabular}{|c|c|c|c|c|c|c|c|}
\hline \multirow[t]{2}{*}{ Parameter } & \multirow[b]{2}{*}{ B } & \multirow[b]{2}{*}{ Std. Error } & \multicolumn{2}{|c|}{$\begin{array}{l}\text { 95\% Wald Confidence } \\
\text { Interval }\end{array}$} & \multicolumn{3}{|c|}{ Hypothesis Test } \\
\hline & & & Lower & Upper & Square & df & Sig. \\
\hline (Intercept) & -1.539 & .5832 & -2.682 & -.396 & 6.965 & 1 & .008 \\
\hline June & 2.443 & .6003 & 1.267 & 3.620 & 16.563 & 1 & .000 \\
\hline July & 1.303 & .6295 & .069 & 2.536 & 4.282 & 1 & .039 \\
\hline August & 1.581 & .6237 & .358 & 2.803 & 6.425 & 1 & .011 \\
\hline September & 1.919 & .6037 & .736 & 3.102 & 10.102 & 1 & .001 \\
\hline October & 1.516 & .6108 & .318 & 2.713 & 6.157 & 1 & .013 \\
\hline December & 1.606 & .6020 & .426 & 2.786 & 7.118 & 1 & .008 \\
\hline January & 1.406 & .6033 & .224 & 2.589 & 5.433 & 1 & .020 \\
\hline February & 1.597 & .6024 & .416 & 2.777 & 7.027 & 1 & .008 \\
\hline March & 1.726 & .6009 & .548 & 2.903 & 8.249 & 1 & .004 \\
\hline May & $0^{\mathrm{a}}$ & . & . & . & . & . & . \\
\hline $5 \%$ sucrose & 4.272 & .5814 & 3.133 & 5.411 & 53.997 & 1 & .000 \\
\hline $10 \%$ sucrose & 4.055 & .5823 & 2.913 & 5.196 & 48.481 & 1 & .000 \\
\hline $30 \%$ sucrose & 4.582 & .5803 & 3.444 & 5.719 & 62.334 & 1 & .000 \\
\hline $5 \%$ casein & 3.060 & .5907 & 1.902 & 4.218 & 26.838 & 1 & .000 \\
\hline $10 \%$ casein & 2.234 & .6075 & 1.043 & 3.424 & 13.518 & 1 & .000 \\
\hline $15 \%$ casein & 2.813 & .5944 & 1.648 & 3.978 & 22.402 & 1 & .000 \\
\hline Control & $0^{\mathrm{a}}$ & . & . & . & . & . & . \\
\hline Soil temperature & .094 & .0056 & .083 & .106 & 281.060 & 1 & .000 \\
\hline Humidity & -.009 & .0008 & -.011 & -.007 & 116.200 & 1 & .000 \\
\hline June*5\% sucrose & -2.555 & .6082 & -3.747 & -1.363 & 17.651 & 1 & .000 \\
\hline June*10\% sucrose & -2.206 & .6086 & -3.399 & -1.013 & 13.139 & 1 & .000 \\
\hline June* $30 \%$ sucrose & -2.409 & .6057 & -3.596 & -1.222 & 15.815 & 1 & .000 \\
\hline June $* 5 \%$ casein & -2.779 & .6296 & -4.013 & -1.545 & 19.488 & 1 & .000 \\
\hline June* $10 \%$ casein & -2.261 & .6510 & -3.537 & -.985 & 12.061 & 1 & .001 \\
\hline June* $15 \%$ casein & -2.399 & .6310 & -3.636 & -1.162 & 14.452 & 1 & .000 \\
\hline June*Control & $0^{\mathrm{a}}$ & . & & . & . & . & . \\
\hline July*5\% sucrose & -1.808 & .6370 & -3.057 & -.560 & 8.057 & 1 & .005 \\
\hline July* $10 \%$ sucrose & -1.420 & .6373 & -2.669 & -.171 & 4.966 & 1 & .026 \\
\hline July*30\% sucrose & -1.348 & .6338 & -2.590 & -.106 & 4.522 & 1 & .033 \\
\hline July*5\% casein & -1.941 & .6572 & -3.229 & -.653 & 8.724 & 1 & .003 \\
\hline July*10\% casein & -1.369 & .6767 & -2.695 & -.042 & 4.091 & 1 & .043 \\
\hline July*Control & $0^{\mathrm{a}}$ & . & . & . & . & . & . \\
\hline August*5\% sucrose & -2.038 & .6321 & -3.277 & -.800 & 10.401 & 1 & .001 \\
\hline August*10\% sucrose & -1.652 & .6322 & -2.891 & -.413 & 6.826 & 1 & .009 \\
\hline August*30\% sucrose & -1.823 & .6291 & -3.056 & -.590 & 8.396 & 1 & .004 \\
\hline August*Control & $0^{\mathrm{a}}$ & . & . & . & . & . & . \\
\hline
\end{tabular}

Table 1.3. Argentine ants generalized linear model of carbohydrate and protein preference experiment. Dependent variable was number of ants. Parameters tested were: month, food type, soil temperature, humidity and month*food type. Only data from the third hour observations was analysed. $0^{a}$ : Set to zero because this parameter is the baseline. 


\begin{tabular}{|c|c|c|c|c|c|c|c|}
\hline September*5\% sucrose & -1.997 & .6094 & -3.192 & -.803 & 10.739 & 1 & .001 \\
\hline September* $10 \%$ sucrose & -1.593 & 6099 & -2.788 & -.397 & 6.820 & 1 & .009 \\
\hline September* $30 \%$ sucrose & -1.644 & .6072 & -2.834 & -.453 & 7.327 & 1 & .007 \\
\hline September* $5 \%$ casein & -1.856 & .6232 & -3.078 & -.635 & 8.873 & 1 & .003 \\
\hline September*Control & $0^{\mathrm{a}}$ & . & & & & . & . \\
\hline October* $5 \%$ sucrose & -1.762 & .6161 & -2.969 & -.554 & 8.178 & 1 & .004 \\
\hline October* $10 \%$ sucrose & -1.357 & .6166 & -2.565 & -.148 & 4.843 & 1 & .028 \\
\hline October* $30 \%$ sucrose & -1.533 & .6140 & -2.737 & -.330 & 6.236 & 1 & .013 \\
\hline October*Control & $0^{\mathrm{a}}$ & & & & & . & . \\
\hline November* $5 \%$ sucrose & -2.107 & .6462 & -3.374 & -.840 & 10.631 & 1 & .001 \\
\hline November* $10 \%$ sucrose & -1.637 & .6457 & -2.903 & -.372 & 6.432 & 1 & .011 \\
\hline November* $30 \%$ sucrose & -1.805 & .6424 & -3.064 & -.546 & 7.892 & 1 & .005 \\
\hline November*Control & $0^{\text {a }}$ & & & & & . & . \\
\hline December* $5 \%$ sucrose & -2.804 & .6086 & -3.996 & -1.611 & 21.224 & 1 & .000 \\
\hline December* $10 \%$ sucrose & -2.384 & .6086 & -3.577 & -1.191 & 15.345 & 1 & .000 \\
\hline December* $30 \%$ sucrose & -2.333 & .6048 & -3.519 & -1.148 & 14.878 & 1 & .000 \\
\hline December* $10 \%$ casein & .143 & .6307 & -1.094 & 1.379 & .051 & 1 & .821 \\
\hline December* $15 \%$ casein & -.145 & .6176 & -1.355 & 1.066 & .055 & 1 & .815 \\
\hline December*Control & $0^{\mathrm{a}}$ & & & & & . & . \\
\hline January*5\% sucrose & -2.432 & .6077 & -3.623 & -1.241 & 16.014 & 1 & .000 \\
\hline January*10\% sucrose & -1.752 & .6073 & -2.942 & -.562 & 8.323 & 1 & .004 \\
\hline January* $30 \%$ sucrose & -2.083 & .6050 & -3.269 & -.898 & 11.858 & 1 & .001 \\
\hline January* $10 \%$ casein & .482 & .6308 & -.755 & 1.718 & .583 & 1 & .445 \\
\hline January* $15 \%$ casein & .275 & .6177 & -.936 & 1.486 & .198 & 1 & .656 \\
\hline January*Control & $0^{\mathrm{a}}$ & . & . & . & . & . & . \\
\hline February*5\% sucrose & -2.173 & .6069 & -3.362 & -.983 & 12.814 & 1 & .000 \\
\hline February* $10 \%$ sucrose & -1.822 & .6075 & -3.013 & -.631 & 8.996 & 1 & .003 \\
\hline February*30\% sucrose & -2.015 & .6049 & -3.200 & -.829 & 11.093 & 1 & .001 \\
\hline February*Control & $0^{\mathrm{a}}$ & & & & & . & . \\
\hline March*5\% sucrose & -2.228 & .6058 & -3.416 & -1.041 & 13.534 & 1 & .000 \\
\hline March*10\% sucrose & -1.846 & .6063 & -3.034 & -.658 & 9.272 & 1 & .002 \\
\hline March*30\% sucrose & -1.976 & .6036 & -3.159 & -.793 & 10.719 & 1 & .001 \\
\hline March*Control & $0^{\mathrm{a}}$ & . & . & . & & . & . \\
\hline
\end{tabular}

Table 1.3. continued. Argentine ants generalized linear model of carbohydrate and protein preference experiment. Dependent variable was number of ants. Parameters tested were: month, food type, soil temperature, humidity and month*food type. Only data from the third hour observations was analysed. $0^{\mathrm{a}}$ : Set to zero because this parameter is the baseline. 


\begin{tabular}{|c|c|c|c|c|c|c|c|}
\hline \multirow[t]{2}{*}{ Parameter } & \multirow[b]{2}{*}{ B } & \multirow{2}{*}{$\begin{array}{l}\text { Std. } \\
\text { Error }\end{array}$} & \multicolumn{2}{|c|}{ 95\% Wald Confidence Interval } & \multicolumn{3}{|c|}{ Hypothesis Test } \\
\hline & & & Lower & Upper & $\begin{array}{c}\text { Wald Chi- } \\
\text { Square }\end{array}$ & df & Sig. \\
\hline (Intercept) & -4.639 & .5550 & -5.727 & -3.551 & 69.867 & 1 & .000 \\
\hline Time $=1$ & -.687 & .0991 & -.881 & -.492 & 47.971 & 1 & .000 \\
\hline Time $=2$ & -.234 & .0448 & -.322 & -.146 & 27.294 & 1 & .000 \\
\hline Time $=3$ & $0^{\mathrm{a}}$ & & . & . & & . & . \\
\hline $5 \%$ sucrose & 2.719 & .2298 & 2.269 & 3.169 & 140.011 & 1 & .000 \\
\hline $10 \%$ sucrose & 2.828 & .2231 & 2.390 & 3.265 & 160.590 & 1 & .000 \\
\hline $30 \%$ sucrose & 3.180 & .2160 & 2.757 & 3.604 & 216.782 & 1 & .000 \\
\hline $5 \%$ casein & .363 & .2936 & -.212 & .938 & 1.528 & 1 & .216 \\
\hline $10 \%$ casein & .241 & .2637 & -.276 & .758 & .836 & 1 & .360 \\
\hline $15 \%$ casein & .237 & .2537 & -.261 & .734 & .870 & 1 & .351 \\
\hline Control & $0^{\mathrm{a}}$ & & & & & . & . \\
\hline Soil temperature & .324 & .0241 & & & 180.674 & 1 & .000 \\
\hline Humidity & -.017 & .0032 & -.023 & -.011 & 29.391 & 1 & .000 \\
\hline Month Group 1: May-Oct & 1.877 & .3119 & 1.266 & 2.488 & 36.207 & 1 & .000 \\
\hline Month Group 2: Nov-April & $0^{\mathrm{a}}$ & & . & . & . & . & . \\
\hline 5\%sucrose*May-Oct & -.008 & .3326 & -.660 & .644 & .001 & 1 & .981 \\
\hline 5\%sucrose*Nov-April & $0^{\text {a }}$ & & & & & & . \\
\hline $10 \%$ sucrose*May-Oct & .143 & .3236 & -.491 & .778 & .196 & 1 & .658 \\
\hline $10 \%$ sucrose*Nov-April & $0^{\mathrm{a}}$ & & & & & & . \\
\hline $30 \%$ sucrose*May-Oct & .353 & .3081 & -.251 & .957 & 1.315 & 1 & .251 \\
\hline 30\%sucrose*Nov-April & $0^{\mathrm{a}}$ & & . & . & . & . & . \\
\hline 5\%casein*May-Oct & -.773 & .4384 & -1.632 & .086 & 3.110 & 1 & .078 \\
\hline 5\%casein*Nov-April & $0^{\mathrm{a}}$ & & & & & . & . \\
\hline $10 \%$ casein*May-Oct & -1.225 & .4205 & -2.049 & -.401 & 8.488 & 1 & .004 \\
\hline $10 \%$ casein ${ }^{*}$ Nov-April & $0^{\mathrm{a}}$ & & & . & & . & . \\
\hline 15\%casein*May-Oct & -1.103 & .4377 & -1.961 & -.245 & 6.348 & 1 & .012 \\
\hline $15 \%$ casein ${ }^{*}$ Nov-April & $0^{\mathrm{a}}$ & & & . & & . & . \\
\hline Control*May-Oct & $0^{\mathrm{a}}$ & & & . & . & . & . \\
\hline Control*Nov-April & $0^{\mathrm{a}}$ & & & & & 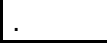 & . \\
\hline
\end{tabular}

Table 1.4. Darwin's ants generalized estimating equations model of carbohydrate and protein preference experiment. Dependent variable was number of ants. Parameters tested were: time, food type, month group (1 or 2), soil temperature, humidity, food type*month group interaction. Only data from the third hour observations was analysed. $0^{\mathrm{a}}$ : Set to zero because this parameter is the baseline. 


\section{Discussion}

Although Argentine and Darwin's ants showed similar preference for Xstinguish ${ }^{\mathrm{TM}}$, Exterm-an-Ant $\AA$ and Advion $₫$ ant gel for much of the year, these ants differed in their carbohydrate and protein preference. Argentine ants significantly preferred protein compared to carbohydrate during December and January, while carbohydrates were consumed year round (but not significantly preferred over protein at any time). For Darwin's ants overall ant numbers were significantly higher in the carbohydrate food groups only compared to the control. Also the overall number of ants on protein groups were not statistically different to the control in the analysis of Darwin's ant preferences and there was no difference in preference between the protein groups. Due to this, it may be more beneficial to design control options based on species specific preferences.

\section{Temporal variation in toxic bait preference}

In Argentine ants and Darwin's ants the preference for Xstinguish ${ }^{T M}$, Exterm-an-Ant ${ }^{\circledR}$ and Advion $®$ ant gel were not statistically different from each other, just from Advion $®$ ant bait arena (Table 1.1 and 2). This is also evident from the mean number of ants per month on each bait type (Figure 1.3 and 1.4). In Darwin's ants there was there was only one statistically significant difference in bait preference between the three most preferred baits. This was between Xstinguish ${ }^{\mathrm{TM}}$ and Advion ${ }^{\circledR}$ ant gel during August, whereby Xstinguish was preferable over Advion gel.

Differences in toxic bait preference are largely influenced by their diverse components. Toxic baits can vary in their attractant, toxin and matrix. An attractant is a particular food source that is appealing to ants and which increases the likelihood of that bait's uptake (Stanley 2004). For my thesis I will refer to the bait matrix as the physical composition of the bait whether it be a gel, paste, granule or liquid matrix. Xstinguish $^{\text {TM }}$ is a protein and carbohydrate paste with the toxin fipronil at a concentration of $0.01 \%$ (Toft and Rees 2009). Exterm-an-Ant ${ }^{\circledR}$ is a liquid carbohydrate bait and its active toxin is boric acid. Advion $\AA$ ant gel is a clear white carbohydrate based gel that contains $0.5 \mathrm{~g} / 1 \mathrm{~kg}$ indoxacarb. Advion $\AA$ ant bait arena contains a protein and carbohydrate mixed paste which contains $1 \mathrm{~g} / 1 \mathrm{~kg}$ indoxacarb. The Advion $®$ ant bait paste is enclosed in a plastic bait arena that ants can enter to retrieve the bait. 
Differences between bait components can affect their uptake and their attractiveness to ant species.

In my experiments both ant species showed a similar preference for Xstinguish ${ }^{\mathrm{TM}}$, Exterm-an-Ant $\AA$ and Advion $®$ ant gel despite differences in bait matrix and toxins. I am unsure about why Advion $®$ ant bait arena was consistently unattractive to either ant species, but a possibility might be due to its high toxin concentration $11 \mathrm{~g} / 1 \mathrm{~kg}$ indoxacarb) which may repel ants. Repellency in Argentine ants has been found before, whereby Argentine ants showed a significant reduction in the consumption of sucrose water containing $>1,2$, and $4 \%$ boric acid compared to plain sucrose water (Klotz et al. 2000). To my knowledge indoxacarb related repellency in Argentine ants has not been researched, but other ant species like the red imported fire ant have shown no discrimination in uptake between different concentrations of indoxacarb (Furman and Gold 2006). Bait application with Xstinguish ${ }^{\mathrm{TM}}$, Exterm-an-Ant $\AA$ or Advion $®$ ant gel individually or in combination with one another could be beneficial for the treatment of these ant species, because my experiments show all three baits are similarly preferred all year round. Darwin's ants did show a significant preference for Xstinguish ${ }^{\text {TM }}$ during August, so baiting with Xstinguish ${ }^{\mathrm{TM}}$ around this period may increase bait uptake.

It was evident in this study that Xstinguish ${ }^{\text {TM }}$ bait often dried rapidly in the field even on humid and cooler days which greatly limits its field life (Stanley 2004; Pers. Obs.). However it is still a highly attractive bait in Argentine ants when it is fresh and has been successful in reducing Argentine ant populations (Toft 2010; Stanley 2004). Producing a liquid formulation of Xstinguish ${ }^{\text {TM }}$ could also be beneficial as liquids are in a more readily available form for uptake. However, a liquid formulation may only be suitable for household use as it would not be easy to apply on a large scale or on uneven terrain. Darwin's and Argentine ants have a modified proventriculus that allows for the uptake and storage of liquids (Eisner 1957 cited in Kay 2002). To best exploit this physiological mechanism, liquid based baits could maximize bait uptake in these species. Argentine ants have been found to carry food in a liquid form from 91.6\% (Harris 2002) up to 99\% of the time (Markin 1970a). It was often observed during my experiments that ants would have to bite off a part of the Xstinguish ${ }^{\text {TM }}$ bait to carry it back to the colony rather than directly ingesting it as liquid bait would have allowed. Having to break small parts of the bait off may be time consuming for individual ants and might reduce the rate of 
overall bait uptake. Similar findings were observed by Silverman and Roulston (2001) in which Argentine ant workers fed on gel bait for a longer duration compared to liquid baits, but that comparatively more liquid bait was consumed. This was due to the Argentine ant's modified proventriculus allowing a rapid and more efficient uptake of liquids.

The efficacy of toxic bait is reliant on its uptake and its toxicity to the colony. While my study has found bait preferences, and showed that one type of bait is not preferred, this might not matter if a low amount of one bait is effective in killing the colony.

\section{Temporal variation in carbohydrate and protein preference}

For Argentine ants overall ant numbers on each of the food groups was significantly different to the control (Figure 1.5, 1.6). The protein groups had significantly more ants on average compared to the carbohydrate groups during December and January, but during no month were carbohydrates significantly preferred over protein. For Darwin's ants overall ant numbers were significantly higher in the carbohydrate food groups only compared to the control (Figure 1.7). The overall number of ants on protein groups were not statistically different to the control in the analysis of Darwin's ant preferences and there was no difference in preference between the protein groups.

Protein consumption has previously been linked to when colonies start reproducing and require protein for brood growth and development and egg production (Markin 1970b; Rust et al. 2000; Abril et al. 2007). Protein is distributed mainly to the queens and larvae (Vega and Rust 2001) and a small amount is retained by worker ants (Markin 1970b). Many studies have found that Argentine ants highest rate of protein uptake occurs around the spring period; during late winter to spring (Rust et al. 2000), mid spring (October) (Toft 2010), spring (Abril et al. 2007) and mid-late spring (October-November) (Markin 1970a). In my study, while there was no significant preference for protein during spring, Argentine ants showed a mean increase in protein uptake from July onwards until it peaked in October (Figure 6A). For Darwin's ants, there was a significantly low interest in the $10 \%$ and $15 \%$ protein groups compared to the control during the May-October period (mid winter-mid spring), suggesting that Darwin's ants might not have been undergoing reproduction (Table 1.4). However brood production was evident in the field throughout September-February (spring and 
summer months). Additionally there was no significant preference for any of the protein groups and no detectable increase of ant numbers on casein protein over the year strongly suggesting casein protein was unattractive to these ants (Figure 1.7). A supplementary experiment revealed that Darwin's ants did indeed find casein protein unattractive when other forms of protein were offered (See Appendix 1).

After the first peak of protein uptake in October for Argentine ants, a second peak occurred in December and January which had significantly higher ant numbers than the carbohydrate groups (Table 1.3). Such second peaks in protein uptake have also been observed in other studies which correlated to a second weaker reproductive period (Markin 1970a; Rust et al. 2000; Abril et al. 2007). A second wave of reproductive behaviour could be the result of a large amount of larvae entering pupation which would require more protein for their growth (Toft 2010). For this study the second peak in protein uptake in December and January had higher mean ant numbers than the initial peak in October (Figure 1.5). The large decline in ant numbers in November was possibly a result of the low rainfall that month and subsequent reduction in soil moisture, which have been shown to influence Argentine ant populations elsewhere (Menke and Holway 2006; Walters and Mackay 2003; Heller and Gordon 2006). Ants produced during the spring reproductive period may have experienced a reduction in numbers due to the low rainfall in November. Protein uptake did begin to increase during July-October possibly signifying ant colonies entering reproductive activities and then sharply decline in November (Figure 1.5). Therefore the second wave of reproduction evident as a significant protein preference in December-January may have been larger to counteract these possible losses. Alternatively, ants may have been deeper down into the soil column to avoid desiccation during November and therefore fewer ants were actively foraging (Vega and Rust 2001).

Both species showed a strong preference for carbohydrate (versus control) year round which is a similar result to that observed in previous studies (Keall and Somerfield 1980; Don 2007; Rust et al. 2000; Abril et al. 2007). Carbohydrates are a source of energy to sustain foraging activity and are utilized mainly by worker ants and a small amount may also be given to queens and larvae (Markin 1970b; Abril et al. 2007). Carbohydrate preference for Argentine ants was not significantly higher than protein preference year round. All of the carbohydrates had significantly higher ant 
numbers compared to the control during August-March. The highest mean numbers of ants on carbohydrates compared to protein occurred during April-June and JulySeptember (Figure 1.6). For Darwin's ants overall ant numbers were significantly higher in all of the carbohydrate food groups compared to the control. There was a substantial increase in mean ant numbers for all carbohydrate groups from July-October (Figure 1.7).

In the carbohydrate and protein experiments, Argentine ants showed an overall mean preference for the highest concentration carbohydrate and highest concentration protein compared to the other concentrations (Figure 1.5, 1.6). Darwin's ants showed an overall preference for the $30 \%$ sucrose group compared to the other carbohydrate concentrations (Figure 1.7). In both ant species, there was no significant difference between overall ant numbers in carbohydrate and protein groups for a most preferred concentration. A preference for the higher concentrated nutrients suggests they were the most nutritionally valuable to these ants. The higher concentration food items may have been preferred as it would be more efficient and productive for an ant to collect resources that are in a more concentrated form. Similar results in red imported fire ants have found the ants showed a higher preference for more concentrated food sources over dilute ones (Cassill and Tschinkel 1999).

Carbohydrates and proteins are macronutrients which have unique biochemical properties and different levels of these obtained through diet can produce very different physical consequences (Kay et al. 2010). It is well documented that invasive ants monopolise food sources such as hemipteran honeydew so they have energy to fuel aggression and activity and thus maintain their ecological dominance (Kay et al. 2010; Markin 1970a; Grover et al. 2007; Rowles and Silverman 2009). It has been suggested that the success of Argentine ant's establishment in new environments is limited by carbohydrate supply. For example, an artificial carbohydrate source was set up in a previously unaffected environment resulting in increased ant abundance into the area (Rowles and Silverman 2009). Argentine ant colonies have also been found to become less aggressive and less active when deprived of sucrose but not when deprived of prey (Grover et al. 2007). These studies highlight the significance of carbohydrates for the establishment and persistence of invasive ant species. 
The importance of protein in invasive ant species is linked to development and growth potential. Different ratios of protein uptake are important in producing a high amount of brood and maintaining worker ant survival. A study on laboratory colonies of Argentine ants found that amongst high, low and zero levels of protein fed colonies, the colonies fed the highest level of protein had the highest number of brood and surviving workers (Grover et al. 2007). Another study on protein allocation in Argentine ant colonies determined that there was no significant difference in the number of queens, workers and male ants produced when intermediate and high levels of protein were provided, suggesting a possible threshold whereby additional protein has no influence on reproduction (Aron et al. 2001).

\section{Conclusion}

These experiments have produced some important information to help with the future control of these ant species. While there was not a lot of difference between the toxic baits Xstinguish ${ }^{\mathrm{TM}}$, Exterm-an-Ant ${ }^{\circledR}$ and Advion $\AA$ ant gel, all three baits were highly preferable by both species year round compared to Advion® ant bait arena. Advion® ant bait arena was not very attractive to either ant species, but was occasionally fed from, often when ant density was extremely high and when all other baits were mostly occupied (Pers. Obs.). Combining the findings from the food preference tests, a strategy for future baiting could involve using Xstinguish ${ }^{\text {TM }}$ in spring time and summer when Argentine ants are undergoing reproduction. Xstinguish ${ }^{\mathrm{TM}}$ would be a good choice as it is contains protein which would target queens and larvae, while Exterm-an-Ant $₫$ and Advion ${ }^{\circledR}$ ant gel only contain carbohydrates. Problems with baiting have often occurred from a lack of follow up treatments, so bait application at both of these times, might reduce numbers greatly (Stanley 2004). Darwin's ants showed a significant preference

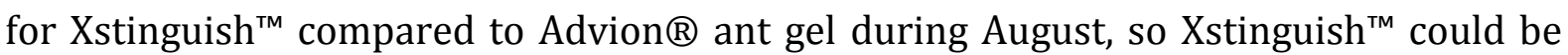
used at this time to see if it has an obvious knockdown on ant numbers. Alternatively bait application with Xstinguish ${ }^{\mathrm{TM}}$, Exterm-an-Ant $\AA$ or Advion ${ }^{\circledR}$ ant gel individually or in combination with one another could be beneficial for the treatment of these ant species as not only are they similarly preferred, but they all contain carbohydrates which both ant species readily consume year round. 
The differences in toxic bait preference revealed how bait formulations can strongly influence bait uptake. Although I observed distinct preferences for carbohydrates and protein at different times of the year, the toxic bait experiments showed that Xstinguish $^{\mathrm{TM}}$, Exterm-an-Ant $\AA$ and Advion $\AA$ ant gel were consistently popular in both ant species despite diverse differences in attractant, matrix and toxin. Advion ${ }^{\circledR}$ ant bait arena contains both protein and carbohydrate attractants, yet it was mostly unattractive for both ant species indicating problems with toxin level, choice of attractant and/or matrix. Even though toxic bait preferences were evident from this study, the critical aspect of toxic bait efficacy is its ability to kill queens and brood. A bait may be highly attractive to ants, but if it mainly kills worker ants and not the queens and brood, then it is at most, only controlling ant numbers without getting to the cause of the problem. It is also possible that a bait with low uptake might be as or more effective than a bait with high uptake due to the toxin level and/or assimilation of toxin within individuals and colonies. Investigating toxic bait efficacy is the subject of the next chapter. 


\title{
Chapter 3:
}

\section{Toxic bait efficacy in laboratory colonies of the Argentine ant (Linepithema humile) (Hymenoptera: Formicidae)}

\begin{abstract}
The success of a toxic bait should be judged by its ability to kill an entire ant colony. It is a complex balance to create a bait that will be palatable and attractive and also slow acting and non-repellent to maximize the colonies exposure to the toxin. It is also fundamental that the toxin remains effective when diluted through the levels of the colonies via trophallaxis (Rust et al. 2004; Stanley 2004). I studied the efficacy of four toxic baits (Xstinguish ${ }^{\mathrm{TM}}$, Exterm-an-Ant ${ }^{\circledR}$, Advion $\AA$ ant gel and Advion $\AA$ ant bait arena) in laboratory colonies of Argentine ants (Linepithema humile). Nest boxes were set up to contain 300 workers and 10 queen ants and each colony was starved for either 24 hours or 48 hours prior to toxic bait exposure. Toxic baits were provided for three hours then the bait was removed. Every 24 hours, for a 21 day period, the number of dead ants was recorded. Xstinguish ${ }^{\mathrm{TM}}$ and Exterm-an-Ant ${ }^{\circledR}$ baits produced the highest mortality rate whereby all colonies were dead in seven and fourteen days, respectively. The other two baits were less effective and their highest mortality rates were $49 \%$ mortality rate of worker ants in the 48 hour starvation Advion $₫$ ant gel treatments and a $11 \%$ mortality rate of worker ants in the 24 hour starvation Advion $®$ ant bait arena treatments. Advion $\AA$ ant gel only produced a queen mortality rate of $5 \%$ in the 48 hour starvation treatments and Advion $®$ ant bait arena treatments did not kill any queen ants. The efficacy of even highly toxic baits was influenced by the degree of hunger within the colony, wherein colonies starved for 24 hours prior to toxin exposure did not suffer mortality rates as high as colonies starved for 48 hours (with the exception of Advion $₫$ ant bait arena treatments). Due to the strong influence of starvation on bait uptake, by applying bait in the field when ants are more likely to be starved may maximize bait uptake. Previous research suggests ants are more likely to be starved when temperatures are low, such as late autumn-early spring.
\end{abstract}




\section{Keywords}

Argentine ants (Linepithema humile); Toxic bait efficacy; mortality rate; Xstinguish ${ }^{\mathrm{TM}}$, Exterm-an-Ant $\AA$; Advion $\AA$ ant gel; Advion $\AA$ ant bait arena ; fipronil; boric acid; indoxacarb

\section{Introduction}

The ability to control invasive ant infestations is largely limited by bait efficacy, bait uptake and the cost of baiting. For a bait to be effective (in killing an entire colony) it must contain a non repellent toxin, have delayed toxicity, and remain toxic when diluted through trophallaxis (Rust et al. 2004; Stanley 2004). To improve control options bait efficacy of commercially available baits needs to be further investigated so we can determine which baits to use. In Chapter 2, I found there were differences in toxic bait preferences of field colonies, but here I am examining toxic bait efficacy in laboratory colonies.

Bait formulations are designed to include highly attractive food sources to ants to maximize bait uptake. The Argentine ant's diet predominantly consists of liquid foods such as honeydew and nectar, with additions of protein sources such as insects (Markin 1970a; Vega and Rust 2001; Harris 2002; Abril et al. 2007; Rust et al. 2000). Darwin's ants have a similar preference for carbohydrates such as honeydew and it has been identified that they can feed on insects (Taylor 1959; Keall 1979; Pers. Obs.). Many bait formulations have been made with these food preferences in mind. Solutions containing sugar water and a toxin have been highly palatable and successful in reduction of Argentine ants (Rust et al. 2004; Hooper-Bui and Rust 2000; Klotz et al. 2000), and similarly baits containing proteins have been palatable and effective (Stanley 2004; Toft and Rees 2009).

Recommendations for the control of Argentine ants with toxic baits are varied. Stanley (2004) suggested that Xstinguish ${ }^{\mathrm{TM}}$ bait may be the best currently available choice in New Zealand for control of Argentine ants. Other research has determined boric acid and fipronil (active toxin in Xstinguish ${ }^{\mathrm{TM}}$ ) as being an effective and non repellent source for controlling Argentine ants (Hooper-Bui and Rust 2000; Vega and Rust 2003; Klotz et al. 1998). A laboratory comparison of baits in Argentine ant colonies revealed that 
Xstinguish $^{\mathrm{TM}}$ and Advion ${ }^{\circledR}$ ant bait arena s provided a similar mortality rate as both baits contained a protein source which suggests that bait reaches the queens and larvae more effectively (Toft and Rees 2009).

The uptake of toxic baits may be influenced by factors such as hunger level of a colony and food type (Markin 1970b). Starving ant colonies before experiments are conducted is a common method used to achieve a uniform level of hunger within the colony (Greenberg and Klotz 2000; Hooper-Bui and Rust 2000; Silverman and Roulston 2001). A uniform level of hunger is fundamental for laboratory tests as bait uptake has been found to be influenced by the hunger level of individual ants (O'Brien and Hooper-bùi 2005). To test whether starvation is an influence in Argentine ant's bait uptake I starved colonies for 24 hours and 48 hours.

In this experiment I compared the efficacy of toxic baits in laboratory colonies of Argentine ants under different degrees of hunger. I used four commercially available toxic baits that differed in the type of attractant, matrix and toxin. The toxic baits used were Xstinguish $^{\mathrm{TM}}$, Exterm-an-Ant ${ }^{\circledR}$, Advion $\AA$ ant gel and Advion $\AA$ ant bait arena. Xstinguish $^{\mathrm{TM}}$ contains the toxin fipronil and egg (protein) and sucrose (carbohydrate) (Stanley 2004). Exterm-an-Ant ${ }^{\circledR}$ contains $8 \%$ boric acid and $5.6 \%$ sodium borate and a sweet carbohydrate solution (Stanley 2004). Advion ${ }^{\circledR}$ ant gel is a carbohydrate bait, Advion $\AA$ ant bait arena contains both a protein and carbohydrate food source, and both Advion ${ }^{\circledR}$ baits contain the toxin indoxacarb. This experiment was also going to be conducted on Darwin's ants, but Darwin's ants failed to acclimatize to laboratory conditions. Darwin's ants were very difficult to sustain in laboratory colonies. When housed in plastic nest boxes (the same type of nest boxes that Argentine ants were housed in) with bark and dirt for nesting in and moistened cotton wool to maintain a humid environment, the ants died within two weeks. They would constantly move their eggs and queens around the box suggesting they were highly stressed. They were rarely observed feeding on sugar water or dead flies. This behaviour was noted in six different nests of Darwin's ants. Clay type nest boxes which are better at maintaining humidity were also tested, but these also failed as Darwin's ants would not even move their nests into them. Further testing into laboratory handling of Darwin's ants is essential before laboratory experiments on bait toxicity can be performed. 


\section{Materials and methods}

Experiments were carried out in laboratory colonies of Argentine ants. All Argentine ants were collected from one location at Ranzau Road, Hope ( $41^{\circ} 35^{\prime}$ S, $\left.173^{\circ} 15^{\prime} \mathrm{E}\right)$. No other experiments or baiting were carried out at this site which may have influenced the ant population.

Five nest boxes $(12.5 \mathrm{~cm} \times 13 \mathrm{~cm})$ were set up, each containing a plastic vial $(1.5 \mathrm{~cm} \mathrm{x}$ $5 \mathrm{~cm}$ ) to act as a nesting chamber. The sides of the nest boxes were coated with Fluon to prevent ants from escaping. To provide food two cotton wool balls per nest were soaked in either $30 \%$ sucrose: water or $15 \%$ casein: water. There was also a plain water cotton wool ball to provide some moisture inside the nest box. Every second day all of the cotton wool balls were replaced with fresh ones to prevent disease within the colony.

Each nest box was set up as seen in Figure 2.1a and 2.1b. Additionally the sides of the nest boxes were covered with tin foil and a removable piece of cardboard was placed on the lid to ensure the nest box was dark inside. The cardboard lid was only removed to make observations, remove dead ants and change cotton wool balls. Each nest box was set up to contain ten queens and approximately 300 worker ants. There were always a few eggs and larvae present in each nest box as these were carried in by worker ants or laid by queens during the experiment which was unavoidable. Each nest box had one colony in it and these colonies were only used once then any remaining ants alive at the end of the experiment were discarded and then new, fresh colonies were put into the nest box. Each colony was given 6 days to acclimatize to conditions inside the nest box prior to the start of the experiment. 


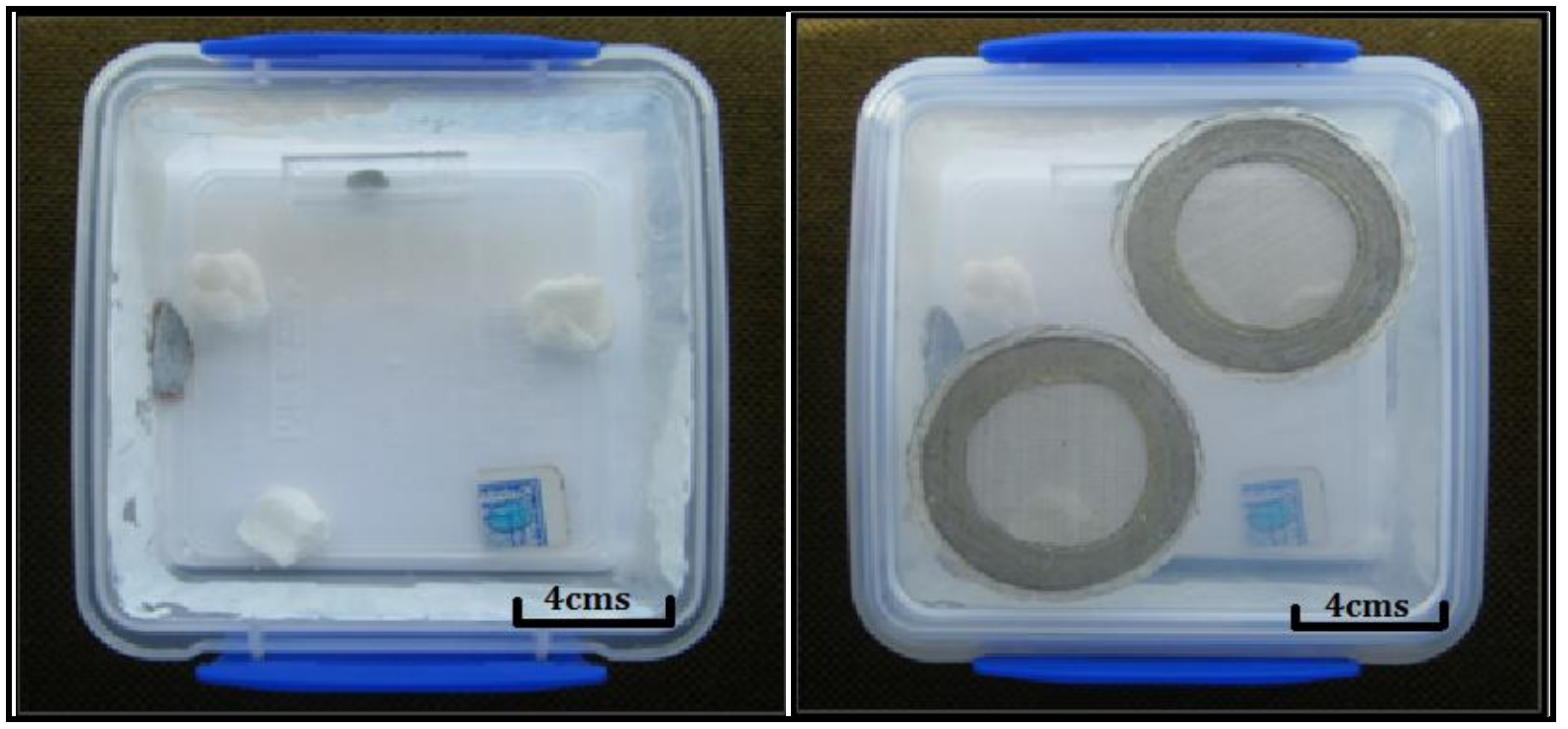

Figure 2.1a (left). Nest box set up. Small plastic vial visible at the top of the nest box is the nesting chamber. Exterm-an-Ant ${ }^{\circledR}$ bait is on cardboard card in bottom right hand corner of box. Three cotton wool balls that provide food and water are also visible. 2.1b (right). Nest box with lid. Lid had two mesh air holes.

After the acclimation period each of the five nest boxes had their food sources removed, except for one cotton wool ball with water which was left to maintain the moisture levels inside the nest box. Each nest box was then starved for either 24 hours (in the "24 hour treatment") or 48 hours (in the "48 hour treatment") prior to toxic bait introduction. After 24 hours a plastic coated card with toxic bait on it was put into the nest box and left there for three hours. Each nest box was given either Xstinguish ${ }^{\mathrm{TM}}$, Exterm-an-Ant $\AA$, Advion $®$ ant gel, Advion $₫$ ant bait arena, or its normal food (control nest box). After three hours the toxic bait was removed and normal food (sugar water and casein water) was put back into the nest boxes. After 24 hours the number of dead ants were counted and removed and this continued for a total of 21 days.

Only five nest boxes were set up at any one time. There were two starvation treatments and five bait treatments (including control). Each starvation treatment consisted of four different bait types and a control, and was replicated twice, giving a total of 20 different nest boxes. Nest boxes were set up in a rearing room with daily light-dark cycles of approximately 14 hours of light and 10 hours of dark. The rearing room was maintained at a temperature between $14-20^{\circ} \mathrm{C}$ and humidity varied between 30-45\%. 


\section{Statistical analysis}

I wanted to determine the cumulative survival of ant colonies when exposed to two different treatments. The first treatment was 'toxic bait type' (including control). The second treatment was 'starvation time' and this was either 24 or 48 hours prior to toxic bait exposure. A Cox's proportional hazards model was conducted to model the survival times by the covariates toxic bait type (first treatment), starvation time (second treatment) and nest (two nests per starvation treatment). The Cox's proportional hazards model assumes that the instantaneous probability of mortality (hazard) for an ant varies over time, but that the covariates (toxic bait type, starvation time and nest) influence the hazard by a proportion which does not change over time. There were only two nests within each starvation treatment so the variation in survival between nests was statistically controlled for by including it in the model as a covariate.

For the toxic bait type treatment the baseline was the control group, and in the starvation treatment the baseline was ' 24 hours'. The coefficient b measures the effect of each bait compared to control. The $\exp (\mathrm{B})$ gives the relative mortality risk (relative to control) for each bait. Statistical analyses were performed with PASW Statistics 18 (SPSS Inc., Chicago 2009).

\section{Results}

The results show that the toxic bait type and starvation time $(\mathrm{p}<0.0005)$ were both significantly predictive of the mortality risk (Table 2.1). 'Nest' was also a significant predictor of mortality risk $(\mathrm{p}<0.0005)$. A model without nest as a covariate was also conducted, but the model with nest included had a better fit, although the coefficients were not very different between the two models. We can therefore conclude that the statistical relationships we are seeing in the data are "controlled by nest". This is not suprising given there were only two nests per treatment, so experiments carried out with more replicates would give more clear cut results.

In the toxic bait treatment none of the $95 \%$ confidence intervals (of the $\exp (\mathrm{B})$ ) overlap. Therefore each bait has a statistically different risk of mortality compared to the other bait types. The most lethal bait to least lethal is as follows: Xstinguish ${ }^{\mathrm{TM}}>$ Exterm-an-Ant $\AA^{\circledR}>$ Advion $\AA$ ant gel $>$ control $>$ Advion $\AA$ ant bait arena. Xstinguish ${ }^{\mathrm{TM}}$ 
was the most effective bait (95\% CI, 47.828-96.426) and had a far higher risk of mortality than the next most effective bait Exterm-an-Ant ${ }^{\circledR}$ (95\% CI, 13.063-25.836). The daily risk of mortality was 67.9 times higher in colonies provided Xstinguish ${ }^{\mathrm{TM}}$ compared to the control. In Exterm-an-Ant $®$ fed colonies the mortality risk was 18.14 times higher than the control and was 4.39 times higher in Advion® ant gel than the control. In the Advion $\AA$ ant bait arena colonies the risk of death was $\sim 5$ times lower $(1 / 0.22)$ compared to the control colonies, which may be attributed to the ants finding the Advion ${ }^{\circledR}$ ant bait unpalatable. Xstinguish ${ }^{\text {TM }}$ had the largest effect on survival, followed by Exterm-an-Ant $®$ and Advion $®$ ant gel. Ants on Advion $₫$ ant bait arena had longer survival times, and lower death rates than ants in the control nests (Figure 2.2a, 2.2b, 2.3a, 2.3b). Xstinguish ${ }^{\mathrm{TM}}$ and Exterm-an-Ant ${ }^{\circledR}$ proved to be very attractive to Argentine ants as it was fed from the entire duration it was provided (Pers. Obs.).

In the starvation treatment there was a significant difference $(\mathrm{p}<0.0005)$ between the 24 hour and 48 hour treatments and their effect on mortality risk. Ants on the 48 hour starvation treatment were $6.79 \%$ more likely to die than those on 24 hour starvation. In the 24 hour starvation treatments, Xstinguish ${ }^{\mathrm{TM}}$ was the most effective in reducing worker numbers by $60 \%$ over 21 days. Exterm-an-Ant $\AA$, Advion $\AA$ ant gel and Advion $®$ ant bait arena reduced worker ant numbers over 21 days by 25\%, 19\% and 11\% respectively, compared to the control colonies which only lost 3\% of their worker ant colonies (Figure 2.2a). Queen ants were hardly affected in the 24 hour treatment and the Exterm-an-Ant ${ }^{\circledR}$ was the only bait that reduced queen ants (by an average of 15\%) (Figure 2.2b). The 48 hour treatments were more effective in the baits Xstinguish ${ }^{\mathrm{TM}}$ and Exterm-an-Ant $\AA$ in providing a more rapid mortality rate. Both of these bats had a $100 \%$ mortality rate within six days in Xstinguish $^{\text {TM }}$ and 13 days in Exterm-an-Ant® (Figure 2.3a). All queen ants in the Xstinguish ${ }^{\mathrm{TM}}$ treated colonies were dead by day six and in Exterm-an-Ant ${ }^{\circledR}$ colonies by day 13 (Figure 2.3b). By the end of 21 days, Advion ${ }^{\circledR}$ ant gel had an average mortality loss of $49 \%$ of their worker ants and $5 \%$ of their queens (Figure 2.3a, 2.3b). Similar results were found between Advion $®$ ant bait arena and control, where a $6 \%$ and $10 \%$ reduction in worker ants was evident at 21 days, respectively (Figure 2.3a). Mortality of queen ants was not observed in Advion ${ }^{\circledR}$ ant bait arena or control treatments (Figure $2.3 \mathrm{~b}$ ). 


\begin{tabular}{|c|c|c|c|c|}
\hline Treatment: & B-coefficient & p-value & $\begin{array}{c}\text { exp(B) (mortality } \\
\text { risk) }\end{array}$ & 95\% CI for exp(B) \\
\hline Xstinguish $^{\text {TM }}$ & 4.218 & $<0.0005$ & 67.910 & $(47.828,96.426)$ \\
\hline Exterm-an-Ant $®$ & 2.911 & $<0.0005$ & 18.1371 & $(13.063,25.836)$ \\
\hline Advion® ant gel & 1.480 & $<0.0005$ & 4.393 & $(3.080,6.265)$ \\
\hline Advion Arena & -1.531 & $<0.0005$ & 0.216 & $(0.105,0.447)$ \\
\hline & & & & \\
\hline Starvation time & 1.915 & $<0.0005$ & 6.786 & $(5.592,8.234)$ \\
\hline
\end{tabular}

Table 2.1. Cox's proportional hazards model for toxic bait type and starvation treatment effects on entire colonies mortality risk.

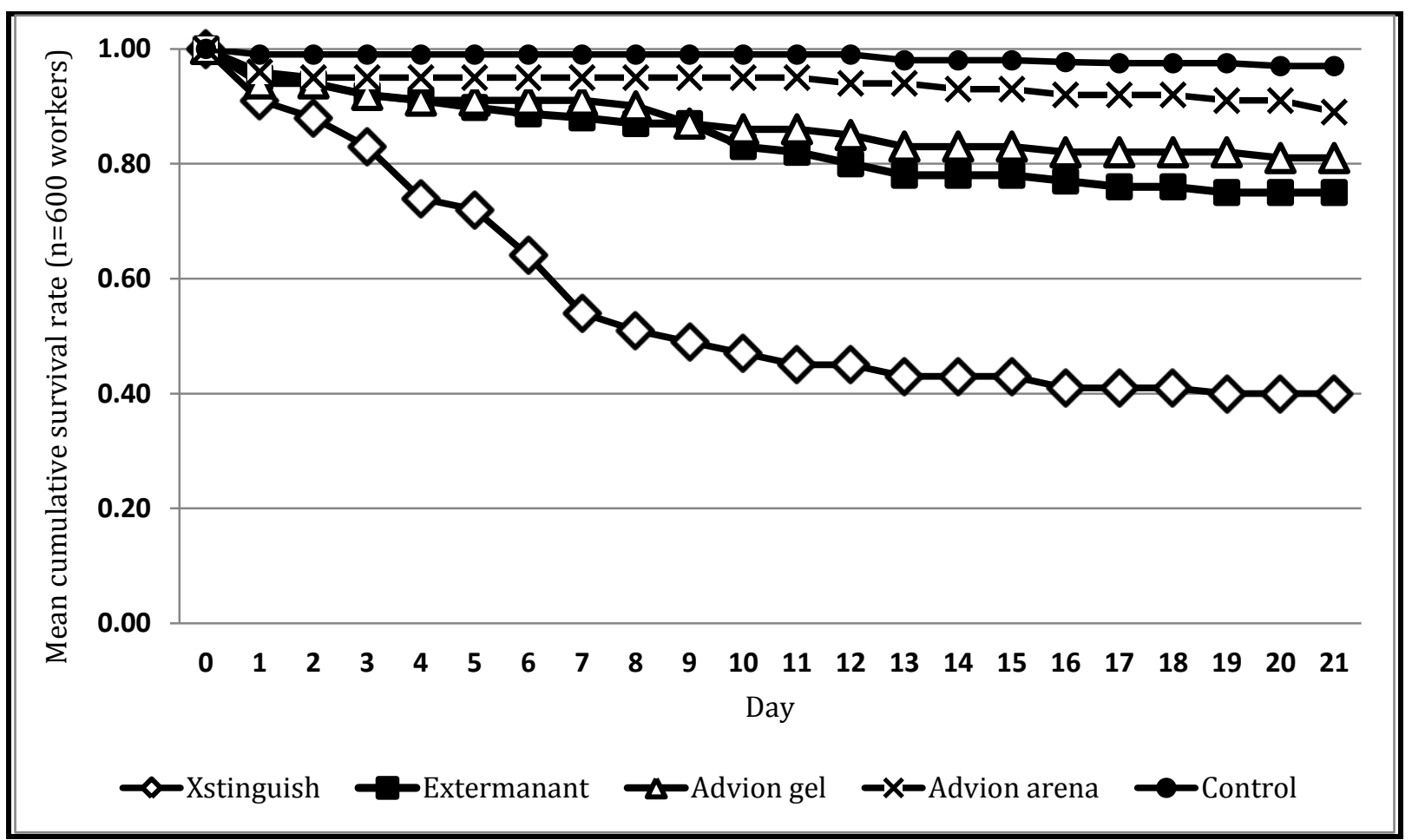

Figure 2.2a. 24 hour starvation treatment. Argentine ant workers mean survival rate in four different toxic baits and control groups. 


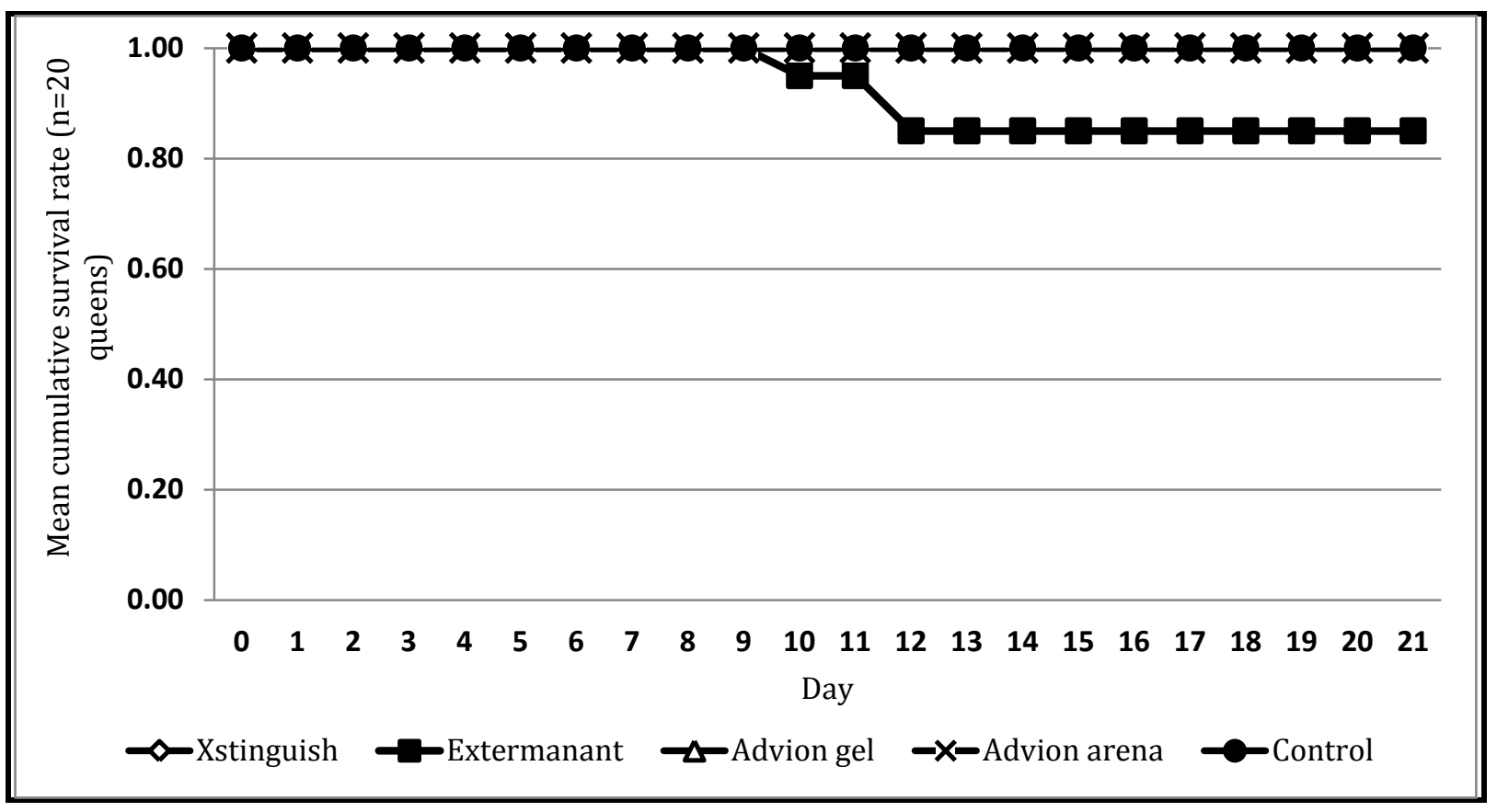

Figure 2.2b. 24 hour starvation treatment. Argentine ant queens mean survival rate. Queens only died in the Exterm-an-Ant ${ }^{\circledR}$ treatment, so all the other treatments with $100 \%$ queen survival rates are overlapping.

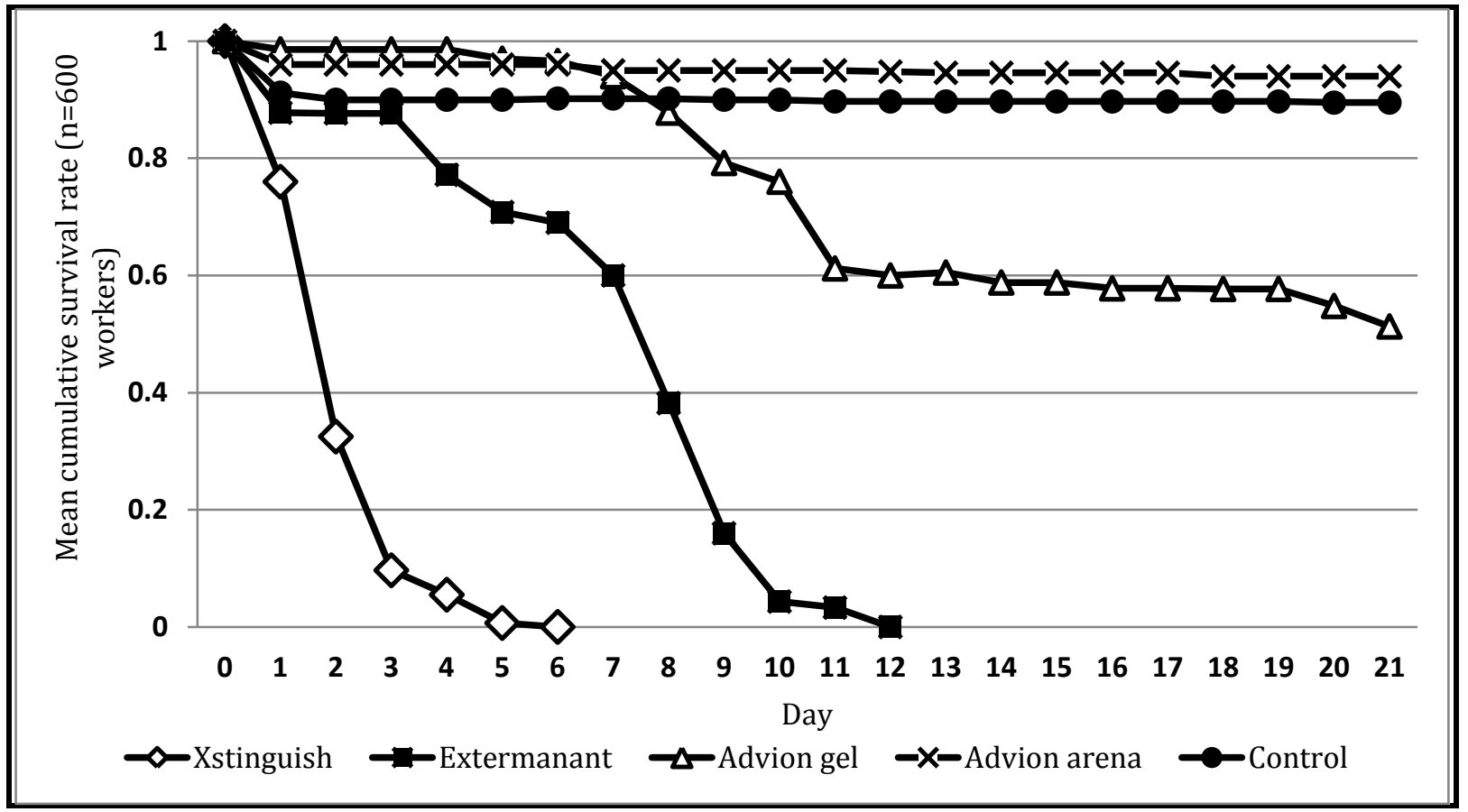

Figure 2.3a. 48 hour starvation treatment. Argentine ant workers mean survival rate in four different toxic baits and control groups. 


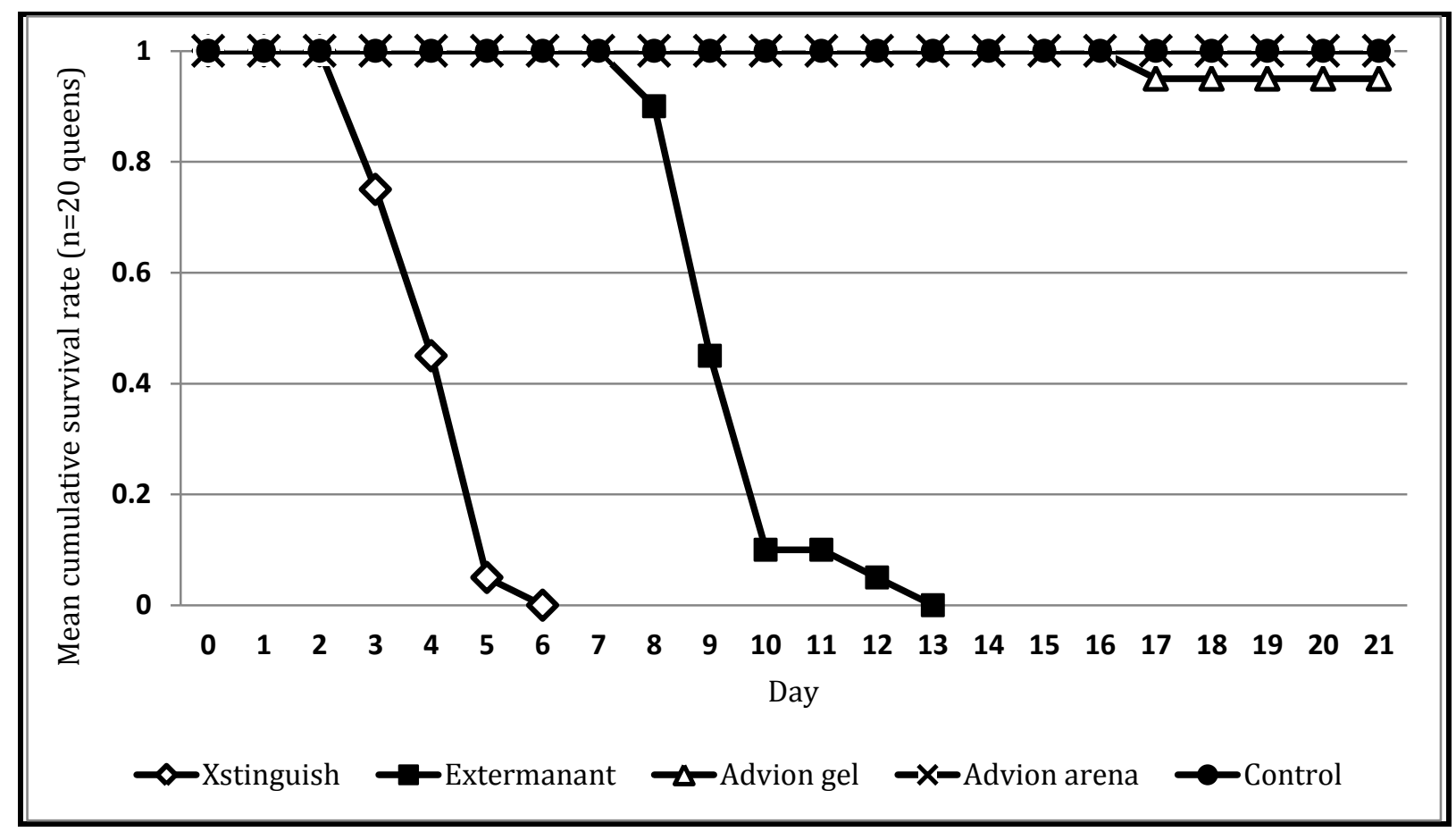

Figure 2.3b. 48 hour starvation treatment. Argentine ant queens mean survival rate. Control and Advion arena groups are overlapping as they had $100 \%$ survival of queens.

\section{Discussion}

\section{Toxic bait efficacy}

I found there was a considerable difference in the efficacy of the four toxic baits tested. The level of starvation in ants greatly increased the efficacy of the toxic baits.

An effective bait should be palatable and attractive, contain a low toxin level, have a relatively long and stable field life and persist in a colony long enough to reach the queens and larvae. The mortality rate was the highest in Xstinguish ${ }^{\mathrm{TM}}$ treated colonies, followed by Exterm-an-Ant ${ }^{\circledR}$, Advion $\AA$ ant gel, control then Advion ${ }^{\circledR}$ ant bait arena. The four toxic baits tested varied widely in their formulation, matrix and toxin. Xstinguish $^{\text {TM }}$ is a protein and carbohydrate bait with $0.01 \%$ fipronil (Toft and Rees 2009). Fipronil works as a neurological inhibitor by blocking neuron receptors (Stanley 2004). Laboratory studies in invasive ant species have determined that exposure to Xstinguish $^{\mathrm{TM}}$ or its toxin, fipronil can cause $100 \%$ mortality rates occurring in a time as 
little as 24 hours (Toft and Rees 2009), or up to seven days (Ulloa-Chacon and Jaramillo 2003; Chong and Lee 2009) or 14 days (Hooper-Bui and Rust 2000).

Exterm-an-Ant ${ }^{\circledR}$ was the second most effective bait, but it only produced a $100 \%$ mortality rate in the 48 hour starvation treatment. Exterm-an-Ant $\AA$ is a liquid carbohydrate bait and contains the toxin boric acid. Boric acid is an accepted and attractive bait to many different ant species as it is water soluble and thus easily incorporated into baits and the toxin (as long as concentrations are of $0.5 \%$ boric acid or less) is relatively slow acting so repellency does not occur (Klotz et al. 2000; Rust et al. 2004; Hooper-Bui and Rust 2000). Therefore Exterm-an-Ant® was surprisingly effective in this study (Exterm-an-Ant ${ }^{\circledR}$ has $8 \%$ boric acid and $5.6 \%$ sodium borate) as literature suggests that toxin levels this high would be repellent and kill ants too fast to affect the entire colony (Klotz et al. 2000; Rust et al. 2004; Hooper-Bui and Rust 2000). Perhaps Exterm-an-Ant ${ }^{\circledR}$ was effective in killing laboratory colonies in this study because colonies were only small and they only had access to one food source (the toxic bait) once they were starving, which would not occur in field colonies. Also carbohydrates are utilized mainly by worker ants, yet toxin can be spread to the queens and larvae through grooming or by toxins mixing with food in the gut/crop of worker ants and then given to the queens and larvae (Markin 1970b; Abril et al. 2007). The liquid formulation of Exterm-an-Ant ${ }^{\circledR}$ would possibly enhance bait uptake as studies have found that Argentine ants consume liquids much faster than gel based baits (Silverman and Roulston 2001). Due to this liquid form a larger amount of toxin can be consumed and spread throughout the colony. Exterm-an-Ant ${ }^{\circledR}$ may have been more successful than the other carbohydrate based bait Advion ${ }^{\circledR}$ ant gel because of these factors.

Advion $\AA$ ant gel is a clear white carbohydrate based gel that contains $0.5 \mathrm{~g} / 1 \mathrm{~kg}$ indoxacarb. Indoxacarb affects ants by blocking the sodium channels in the ant's nervous system (Stanley, 2004). It was found to be effective at reducing worker numbers over 21 days by $49 \%$ in the 48 hour treatment and by $19 \%$ in the 24 hour treatment (Figure 5). Toft and Rees (2009) found similar results in that Advion $®$ ant gel was initially effective at reducing worker ants' activity rates, but it did not provide a $100 \%$ mortality rate, as activity rates increased again. Advion $®$ ant gel mainly killed worker ants in this study (with the exception of 5\% queen mortality in the 48 hour 
starvation treatment), which may be because the toxin was repellent and/or may have killed ants too quickly and therefore not reached the queen ants. A rapid mortality rate in worker ants may have caused the rest of the colony to reject the bait.

Advion ${ }^{\circledR}$ ant bait arena is a protein and carbohydrate mixed bait which contains $1 \mathrm{~g} / 1 \mathrm{~kg}$ indoxacarb. Only a few ants would feed from the Advion® ant bait arena bait in my experiments. This reluctance to eat despite being starved might indicate the ants did not find the bait palatable or the toxin level was too high. This bait contains twice the amount of toxin that Advion $₫$ ant gel contains so it may be that the toxin was detectable in Advion $®$ ant bait arena. Other laboratory experiments have found the opposite result in that Advion ${ }^{\circledR}$ ant bait arena was highly attractive to Argentine ants and it also produced a 100\% mortality rate in 24 hours (Toft and Rees 2009). Advion® ant bait arena bait was just as effective as Xstinguish ${ }^{\text {TM }}$ in Toft and Rees's (2009) trials. Toft and Rees (2009) also starved their ant colonies for 48 hours prior to toxic bait treatment so it is unusual to see such opposite reactions in Argentine ant colonies when exposed to the same toxic bait. I am unsure why these differences occurred between studies. Other studies have determined that indoxacarb produced 100\% mortality in laboratory colonies of red imported fire ants in six days (Oi and Oi 2006). Advion $₫$ ant gel and Advion $\AA$ ant bait arena s both produced a low mortality rate in this experiment.

In this study the Advion $\AA$ ant bait arena treated colonies actually showed survival times longer than control colonies which were not supplied with toxic bait $(\mathrm{p}<0.0005)$. Advion $\AA$ ant bait arena treated colonies only had a $\sim 5$ times (1/0.22) lower risk of daily mortality compared to the control colonies (Table 2.1). It is unknown why this may be, but it could be caused by an inability for control nests to acclimatize as quickly to the nest boxes. More replicated trials would need to be done to determine why this occurred.

\section{Level of starvation and its influence on bait uptake and mortality rate}

Starvation time was a significant influence in the mortality rate of Argentine ants. Even the most effective bait did not result in complete mortality when the ants were starved for 24 hours. A 100\% mortality rate only occurred in Xstinguish ${ }^{\mathrm{TM}}$ and Exterm-an-Ant® treated colonies starved for 48 hours. Xstinguish ${ }^{\mathrm{TM}}$ was the most effective bait with a $100 \%$ mortality rate occurring at seven days $(\mathrm{p}<0.0005)$ (Figure 2.3a, 3B). Exterm-an- 
Ant ${ }^{\circledR}$ was the next most effective bait with a $100 \%$ mortality rate at 14 days $(\mathrm{p}<0.0005)$ (Figure 2.3a, 3B). Advion $®$ ant gel's highest mortality results were $49 \%$ in the 48 hour starvation treatment (Figure 2.3a). The highest mortality rate in the Advion ${ }^{\circledR}$ ant bait arena treatments was $11 \%$ in the 24 hour starvation treatment at 21 days (Figure 2.2a). Advion ${ }^{\circledR}$ ant bait arena was the least effective in terms of queen mortality as neither the 24 hour or 48 hour starvation treatments killed any queen ants.

Bait uptake is influenced by the level of hunger within a colony (Markin 1970b). Twenty four hours of starvation produced a reduced number of worker ants in all toxic bait treatments (Figure 2), but the level of hunger within the colonies was probably not high enough to encourage sufficient bait exchange within the colony. The 48 hour starvation treatments provided $100 \%$ colony mortality in the Xstinguish ${ }^{\mathrm{TM}}$ and Exterman-Ant ${ }^{\circledR}$ treatments only. Perhaps another starvation treatment of 96 hours would increase bait uptake of Advion $\AA$ ant gel and Advion $®$ ant bait arena. Hooper-Bui and Rust (2000) also found that red imported fire ants consumed more bait when starved for 96 hours and this level of hunger was more similar to ants in the field. These levels of starvation are much longer to those conducted in this study; however it could be beneficial to compare starvation levels effect on bait uptake in periods longer than 24 and 48 hours.

From this study it is evident there is a strong influence of starvation level on bait uptake. Due to this, bait uptake in the field may be enhanced by applying bait when ants are more likely to be starved. Ants are more likely to be starved when temperatures are low, such as late autumn-early spring. Keall (1979) suggested that spring and autumn are good times to bait as natural food sources are less abundant. Winter also has less plentiful food sources but ant activity is notably low during this period, so bait uptake would also be low (Abril et al. 2007; Pers. Obs.). Therefore bait application during late winter-spring when ants are not only in a state of starvation, but they are also becoming more active could maximize bait uptake. An optimum time would be to apply bait on a sunny day, immediately after a few days of cold and wet weather. Alternatively, control of aphid populations in combination with ant bait application could maximize bait uptake. Both Argentine and Darwin's ants heavily rely on hemipteran honeydew, so controlling aphid populations either through baiting or spraying would induce hunger in ant colonies, thus encouraging increased uptake of toxic baits. Previous studies have 
had mixed results on whether the manipulation of hemipteran numbers or access to them improves bait uptake in Argentine ants. These studies were possibly limited by ineffective treatment of terrapin scale which did not reduce honeydew sources enough to increase the uptake of offered liquid toxic baits (Brightwell et al. 2010), and also a low number of toxic bait stations did not provide sufficient coverage to reduce ant numbers (Brightwell and Silverman 2009). Further studies on the combined effect of hemipteran treatment and ant bait application would be highly beneficial. 


\section{Chapter 4:}

\section{General discussion}

In New Zealand Argentine and Darwin's ants are well established and Argentine ants especially are spreading at a rapid rate. Previously there has not been thorough research into toxic bait preferences of Argentine and Darwin's ants, so these experiments provided significant new information. Similarly there is little research on toxic bait efficacy in laboratory colonies for the baits Xstinguish ${ }^{\mathrm{TM}}$, Exterm-an-Ant@, Advion $\AA$ ant gel and Advion $®$ ant bait arena. Based on this study's findings, I would recommend that Xstinguish ${ }^{\mathrm{TM}}$ and Exterm-an-Ant ${ }^{\circledR}$ are the best choices for the control of Argentine and Darwin's ants, as these baits were highly preferred year round and they also produced complete mortality in laboratory colonies.

Studies from various regions including New Zealand, Spain, and California, where Argentine ants are established, have found similar seasonal foraging patterns and food preferences between regions (Markin 1970a; Rust et al. 2000; Abril et al. 2007; Toft 2010). My study has also shown similar seasonal changes in food preference whereby protein preference increased from late winter-spring and again in summer and carbohydrates were preferable year round. Also, past research on Darwin's ants in Australia and New Zealand have shown the ants have a strong preference for carbohydrates (Taylor 1959; Keall 1979). Similarity of Argentine and Darwin's ants' food preference across wide ranging and diverse habitats is beneficial as control options can be widely applied. However further studies on food and bait preference within and between different countries where Argentine and Darwin's ants are established would be advantageous to determine if baiting strategies can be globally applicable or region specific. In this study, various populations of both Argentine and Darwin's ants were investigated and they all displayed similar food and bait preferences to one another, suggesting that in this study, a region specific baiting strategy can be applied to each individual species.

There was not a lot of difference between preference of Xstinguish ${ }^{\mathrm{TM}}$, Exterm-an-Ant® and Advion ${ }^{\circledR}$ ant gel, and all three baits were highly acceptable to both species year round. Advion $®$ ant bait arena was consistently not very attractive to either ant species. 
From these results, Advion $®$ ant bait arena is not highly preferred by either of these ant species and thus would not be an effective bait for controlling ant populations. Due to the strong preference of Xstinguish ${ }^{\mathrm{TM}}$ and Exterm-an-Ant ${ }^{\circledR}$ for both species in these experiments, the bait formulations probably do not need to be changed hugely to be more successful, rather the timing of applying the bait should be considered to increase effectiveness. Exterm-an-Ant $®$ is recommended for year round treatment because it was not only successful in producing $100 \%$ mortality rates in entire colonies, but it is also cost effective and easy to use for households. A lack of protein may be an issue when solely using Exterm-an-Ant $\AA$ to control populations, so combining the use of Xstinguish $^{\mathrm{TM}}$ in known reproductively active periods (spring and summer) would be beneficial. Advion ${ }^{\circledR}$ ant bait arena was ineffective in the toxic bait efficacy tests possibly due to disinterest or repellency of the bait or a low uptake rate. Additional laboratory tests on the toxic bait efficacy of Advion $₫$ ant bait arena may show more clear cut results as findings from another study have shown it to be a highly effective and toxic bait (Toft and Rees 2009). However, due to the low preference of Advion $®$ ant bait arena for much of the year in this study, combined with the fact that DuPont (New Zealand) Ltd. withdrew Advion $₫$ ant bait arenas from the market in 2010, I would suggest that further testing on this bait are not necessary.

The critical aspect of toxic bait efficacy is its ability to kill queens and brood. The differences in each toxic bait's efficacy revealed how bait formulations can strongly influence mortality rate, whether it be through different toxin concentrations, formulation and/or matrix. A bait may be highly attractive to ants, but if it mainly kills workers ants and not the queens and brood, then it is at most, only controlling ant numbers without getting to the cause of the problem. Xstinguish ${ }^{\text {тм }}$ was the most successful bait in the bait efficacy experiments. Interestingly enough although $\mathrm{Xstinguish}^{\mathrm{TM}}$ was in a paste form which may have been comparatively more difficult to ingest over the liquid bait Exterm-an-Ant $\AA$ (Silverman and Roulston 2001), its toxin was more effective as it produced a $100 \%$ mortality rate in ant colonies in half the time as Exterm-an-Ant®. Or this finding may suggest that only a small amount of Xstinguish ${ }^{\mathrm{TM}}$ was actually needed to produce a complete mortality rate in the colony and that the concentration of fipronil in Xstinguish ${ }^{\mathrm{TM}}$ was high enough to induce colony death when only a small amount was consumed (and in the shortest time frame). Exterm-an-Ant® 
also produced a $100 \%$ mortality rate, but only after 14 days, twice as long as the Xstinguish $^{\mathrm{TM}}$ treatment. Perhaps this occurred because although Exterm-an-Ant $\AA$ was a liquid and readily attractive to ants, it may have had a lower toxin level resulting in a slower kill rate, and/or it may have taken longer to reach the queens and larvae because it is a carbohydrate bait. Xstinguish ${ }^{\mathrm{TM}}$ was highly toxic but was still not $100 \%$ effective even when colonies starved for 24 hours. This strongly suggests that baiting with Xstinguish $^{\mathrm{TM}}$ may be most effective when ants are in a higher level of starvation. Advion $®$ ant gel was highly preferred in the bait preference experiments, but it was not successful in killing ants in the bait efficacy experiments. This bait appeared to be more effective at killing worker ants rather than queens, but further research would be needed to establish this. Advion $®$ ant gel could be used for large scale infestations to control worker ant numbers as it has a long field life and is easy to apply.

Invasive ants are highly reliant on carbohydrate food sources such as hemipteran honeydew so they have energy to fuel aggression and activity and thus maintain their ecological dominance (Kay et al. 2010; Markin 1970a; Grover et al. 2007; Helms and Vinson 2008; Rowles and Silverman 2009; Savage et al. 2011). It has been suggested that by restricting Argentine ant's access to hemipteran honeydew or reducing hemipteran abundance, it can increase the uptake of carbohydrate based toxic baits. Control of hemipteran abundance and/or access is an exciting idea that provides an alternative control option as opposed to baiting for ant species only. Past studies on Argentine ants have had mixed results in controlling hemipteran abundance and access (Brightwell and Silverman 2009; Brightwell et al. 2010). However these studies were likely to be limited by ineffective hemipteran control agents and also a low number of toxic bait stations which did not provide sufficient coverage to reduce ant numbers.

Food exchange rates can influence the spread of toxic bait through an ant colony. Two key influences on this food exchange rate are the starvation level of an ant colony and temperature. Low temperatures $(<10$ degrees) have been found to reduce food exchange in Argentine ants which would influence bait uptake and subsequent spread of the bait through the colony (Markin 1970b). Argentine ants usually nest within the top $20 \mathrm{~cm}$ of soil to avoid frozen surface soil and cold temperatures (Vega and Rust 2001). As temperatures decline there will be less foraging ants leaving the nest and due 
to this the success of baiting is low. Many studies have found that Argentine ant numbers and foraging rates are lowest in winter (Markin 1970a; DiGirolamo and Fox 2006; Abril et al 2007), but that spring time (October) can also have a low number of foraging ants due to changeable temperatures (Toft 2010). Therefore if temperatures are particularly low for spring and ant numbers are also low, then I would recommend that baiting could be conducted later in spring when temperatures are warmer. This way there will be more foraging ants present to uptake bait. Alternatively baits that contain a low concentration could be used as this will maximise the time that the toxin can circulate throughout a colony (Toft 2010).

Secondly, the starvation level of ants strongly influences food uptake and therefore food exchange rates (O’Brien and Hooper-Bui 2005; my toxic bait efficacy experiment). Due to this, bait uptake in the field may be enhanced by applying bait when ants are more likely to be starved. Ants are more likely to be starved during winter when temperatures are low and natural food sources are also less abundant (Abril et al. 2007; DiGirolamo and Fox 2006). Also Argentine ant queens have been found to be in the highest numbers in nests in winter as nests contract to increase nest temperatures (Abril et al. 2008). Therefore baiting over winter would be optimal, but ant activity is notably low during this period, so bait uptake would also be low (Abril et al. 2007; DiGirolamo and Fox 2006; Pers. Obs.). Depending on temperature and thus foraging rates, bait application during late winter-spring when ants are in a state of starvation could be highly beneficial. Alternatively baits could be applied when ant numbers are highest to maximize the number of foragers exposed to the bait. For both the bait and food preference experiments, both species had the highest ant numbers during the spring and summer months. Argentine ant numbers were the highest during October and December-January, and Darwin's ants numbers were also the highest during September-October and January-February. Both species showed a high interest in carbohydrates year round too, suggesting baiting with a carbohydrate based bait would be attractive to ants whenever it is applied.

Problems with baiting have often occurred from a lack of follow up treatments, so bait application more than once, might reduce numbers greatly (Stanley 2004). A lack of coordinated baiting is also a contributing factor to a low reduction in ant numbers as 
ants from non treated neighboring areas can re-infest quite rapidly (Pers. Obs.). The importance of follow up treatments is to target the remaining brood and queens in colonies that may survive the first round of treatment. Many studies, including this study have observed that Argentine ants have two peaks in protein uptake generally occurring in the spring and summer months (Markin 1970a; Rust et al. 2000; Abril et al. 2007). If bait application is targeted for one time of the year only, a large proportion of new brood, sexual and worker ants may evade toxic bait control. For my study, the first peak in protein uptake was observed in Argentine ants in October (spring) and a second stronger interest in protein uptake occurred in December and January (summer). According to another study, Argentine ant queens produce haploid eggs year round. When queens were experimentally removed from colonies, the female larvae developed into queens and the haploid eggs developed into adult males, allowing the colony to survive (Aron 2001).These studies not only show how difficult Argentine ants are to eradicate due to their reproductive characteristics, but also further highlights how important follow up treatment of colonies is. I would recommend that baiting be carried out during spring and summer to reduce as many worker ants, brood and queens as possible.

Overall, I recommend bait application with Xstinguish ${ }^{\mathrm{TM}}$ and Exterm-an-Ant $\AA$ in late winter-spring, depending on temperatures and foraging activities. If temperatures are $>10$ degrees and there is a high number of ants foraging, baiting can occur in late winter, but if not, baiting can be carried out as soon as temperatures and ant numbers increase, preferably in mid-late spring. This is likely to maximise bait uptake as ants will be starved, and foraging for both food sources for energy (for workers) and protein for queens and brood, so it is likely they will consume either protein or carbohydrate baits. Secondly, I would conduct another round of baiting treatment with both baits (Xstinguish $^{\mathrm{TM}}$ and Exterm-an-Ant ${ }^{\circledR}$ ) in summer when Argentine ants have been shown to undergo a second wave of reproduction. This would hopefully eradicate brood that may have escaped the first round of baiting. Also, if future studies are conducted on hemipteran control and if it has an effect on ant bait uptake, this may provide another important facet to improving baiting strategies of these ant species. 
Future research to complement this study may include:

1. Comparing nocturnal food preferences. Taking samples at night would be interesting and may uncover some new preference patterns, but due to the time limitations and use of residential properties, data collection at night was not possible in this study.

2. Research into toxic bait preferences in laboratory colonies could produce some interesting results which may be applicable to field colonies.

3. Darwin's ants did not readily recruit to casein protein in this study, so the use of another protein source would be beneficial for gaining a better understanding of Darwin's ants' protein uptake (Appendix 1).

4. Testing different conditions that will sustain laboratory colonies of Darwin's ants. Then toxic bait efficacy in laboratory colonies of Darwin's ants can be investigated.

5. Research into effective hemipteran control agents such as baiting, spraying or restricting access to plants.

6. To confirm my findings a field experiment to test starvation effects on bait uptake could be conducted. This experiment could compare three different bait treatments; a highly preferred bait (such as Xstinguish ${ }^{\mathrm{TM}}$ ), a non-preferred bait (such as Advion $囚$ ant bait arena) and a control treatment (no bait). Within each of these bait treatments two starvation treatments would be conducted to induce starvation in ants. These would be by restricting access to carbohydrates (hemipteran honeydew) or by reducing prey availability. Next each bait treatment could be offered to determine if starvation influences bait uptake and therefore a reduction in ant numbers. From my experiments, we would expect a higher reduction in ant numbers in the Xstinguish ${ }^{\mathrm{TM}}$ and starvation treatments. 


\section{Literature cited}

Abril, S., Oliveras, J., and Gomez, C. 2007. Foraging activity and dietary spectrum of the Argentine ant (Hymenoptera : Formicidae) in invaded natural areas of the northeast Iberian Peninsula. Environmental Entomology 36: 1166-1173.

Abril, S., Oliveras, J., and Gomez, C. 2008. Effect of seasonal dynamics on queen densities of the Argentine ant (Linepithema humile) (Hymenoptera: Formicidae) in an invaded natural area of the NE Iberian Peninsula. Sociobiology 51: 645654.

Aron, S. 2001. Reproductive strategy: an essential component in the success of incipient colonies of the invasive Argentine ant. Insectes Sociaux 48: 25-27.

Aron, S., Keller, L., and Passera, L. 2001. Role of resource availability on sex, caste and reproductive allocation ratios in the Argentine ant Linepithema humile. Journal of Animal Ecology 70: 831-839.

Brightwell, R. J., and Silverman, J. 2009. Effects of honeydew-producing hemipteran denial on local Argentine ant distribution and boric acid bait performance. Journal of Economic Entomology 102: 1170-1174.

Brightwell, R. J., Bambara, S. B., and Silverman, J. 2010. Combined effect of hemipteran control and liquid bait on Argentine ant populations. Journal of Economic Entomology 103: 1790-1796.

Buczkowski, G., Kumar, R., Suib, S. L., and Silverman, J. 2005. Diet-related modification of cuticular hydrocarbon profiles of the Argentine ant, Linepithema humile, diminishes intercolony aggression. Journal of Chemical Ecology 31: 829843.

Buczkowski, G., and Bennett, G. W. 2008. Detrimental effects of highly efficient interference competition: Invasive argentine ants outcompete native ants at toxic baits. Journal of Environmental Entomology 37: 741-747.

Cassill, D. L., and Tschinkel, W. R. 1999. Regulation of diet in the fire ant, Solenopsis invicta. Journal of Insect Behavior 12: 307-328.

Chong, K. F., and Lee, C. Y. 2009. Evaluation of liquid baits against field populations of the longlegged ant (Hymenoptera: Formicidae). Journal of Economic Entomology 102: 1586-1590. 
Cliflo. 2011. http://cliflo.niwa.co.nz/ NIWA.

DiGirolamo, L. A., and Fox, L. R. 2006. The influence of abiotic factors and temporal variation on local invasion patterns of the Argentine ant (Linepithema humile). Biological Invasions 8: 125-135

Don, W. 2007. Ants of New Zealand. Otago University Press, Dunedin, New Zealand.

Dussutour, A., and Simpson, S. J. 2008. Carbohydrate regulation in relation to colony growth in ants. Journal of Experimental Biology 211: 2224-2232.

Furman, B. D., and Gold, R. E. 2006. Determination of the most effective concentration and quantity of Advion TM, as well as the most effective placement of the bait for individual Solenopsis invicta mound treatments (Hymenoptera: Formicidae). . Sociobiology 48: 101-116.

Greenberg, L., and Klotz, J. H. 2000. Argentine ant (Hymenoptera : Formicidae) trail pheromone enhances consumption of liquid sucrose solution. Journal of Economic Entomology 93: 119-122.

Grover, C. D., Kay, A. D., Monson, J. A., Marsh, T. C., and Holway, D. A. 2007. Linking nutrition and behavioural dominance: carbohydrate scarcity limits aggression and activity in Argentine ants. Proceedings of the Royal Society B-Biological Sciences 274: 2951-2957.

Harris, R. J. 2002. Potential impact of the Argentine ant in New Zealand and options for its control., pp. 1-36, Science for Conservation. New Zealand Department of Conservation.

Heller, N. E., and Gordon, D. M. 2006. Seasonal spatial dynamics and causes of nest movement in colonies of the invasive Argentine ant (Linepithema humile). Ecological Entomology 31: 499-510.

Helms, K. R., and Vinson, S. B. 2008. Plant resources and colony growth in an invasive ant: The importance of honeydew-producing Hemiptera in carbohydrate transfer across trophic levels. Environmental Entomology 37: 487-493.

Hooper-Bui, L. M., and Rust, M. K. 2000. Oral toxicity of abamectin, boric acid, fipronil, and hydramethylnon to laboratory colonies of argentine ants (Hymenoptera: Formicidae). Journal of Economic Entomology 93: 858-864.

Human, K. G., and Gordon, D. M. 1996. Exploitation and interference competition between the invasive Argentine ant, Linepithema humile, and native ant species. Oecologia 105: 405-412. 
Human, K. G., and Gordon, D. M. 1997. Effects of Argentine ants on invertebrate biodiversity in northern California. Conservation Biology 11: 1242-1248.

Judd, T. M. 2005. The effects of water, season, and colony composition on foraging preferences of Pheidole ceres Hymenoptera : Formicidae. Journal of Insect Behavior 18: 781-803.

Kay, A. 2002. Applying optimal foraging theory to assess nutrient availability ratios for ants. Ecology 83: 1935-1944.

Kay, A. 2004. The relative availabilities of complementary resources affect the feeding preferences of ant colonies. Behavioral Ecology 15: 63-70.

Kay, A. D., Zumbusch, T., Heinen, J. L., Marsh, T. C., and Holway, D. A. 2010. Nutrition and interference competition have interactive effects on the behavior and performance of Argentine ants. Ecology 91: 57-64.

Keall, J. B. 1979. Darwin's ant biology, significance and control. A summary. Ministry of Agriculture and Fisheries.

Keall, J. B., and Somerfield, K. G. 1980. The Australian ant Iridomyrmex darwinianus established in New Zealand (Hymenoptera: Formicidae). New Zealand Entomologist 7: 123-127.

Klotz, J., and Shorey, H. 2000. Low-toxic control of Argentine ants using pheromoneenhanced liquid baits.

Klotz, J. H., Greenberg, L., Amrhein, C., and Rust, M. K. 2000. Toxicity and repellency of borate-sucrose water baits to Argentine ants (Hymenoptera : Formicidae). Journal of Economic Entomology 93: 1256-1258.

Lester, P. J., Baring, C. W., Longson, C. G., and Hartley, S. 2003. Argentine and other ants in New Zealand horticultural ecosystems: distribution, hemipteran hosts, review. New Zealand Entomologist 26: 76-89.

Liang, D., and Silverman, J. 2000. "You are what you eat": Diet modifies cuticular hydrocarbons and nestmate recognition in the Argentine ant, Linepithema humile. Naturwissenschaften 87: 412-416.

Markin, G. 1970a. Foraging behavior of the Argentine ant in a California citrus grove. Journal of Economic Entomology 63: 740-744.

Markin, G. 1970b. Food distribution within laboratory colonies of the Argentine ant, Iridomyrmex humilis (Mayr). Insectes Sociaux 17: 127-157. 
Menke, S. B., and Holway, D. A. 2006. Abiotic factors control invasion by Argentine ants at the community scale. Journal of Animal Ecology 75: 368-376.

NIWA. 2011. http://www.niwa.co.nz/education-andtraining/schools/resources/climate/overview/map_n_south.

O'Brien, K. S., and Hooper-bùi, L. M. 2005. Hunger in red imported fire ants and their behavioral response to two liquid bait products. Journal of Economic Entomology 98: 2153-2159.

Oi, D. H., and Oi, F. M. 2006. Speed of efficacy and delayed toxicity characteristics of fast-acting fire ant (Hymenoptera: Formicidae) baits. Journal of Economic Entomology 99: 1739-1748.

Rowles, A. D., and Silverman, J. 2009. Carbohydrate supply limits invasion of natural communities by Argentine ants. Oecologia 161: 161-171.

Rust, M. K., Reierson, D. A., and Klotz, J. H. 2004. Delayed toxicity as a critical factor in the efficacy of aqueous baits for controlling argentine ants (Hymenoptera : Formicidae). Journal of Economic Entomology 97: 1017-1024.

Rust, M. K., Reierson, D. A., Paine, E., and Blum, L. J. 2000. Seasonal activity and bait preferences of the Argentine ant (Hymenoptera: Formicidae). Journal of Agricultural and Urban Entomology 17: 201-212.

Savage, A. M., Johnson, S. D., Whitney, K. D., and Rudgers, J. A. 2011. Do invasive ants respond more strongly to carbohydrate availability than co-occurring noninvasive ants? A test along an active Anoplolepis gracilipes invasion front. Austral Ecology 36: 310-319.

Shattuck, S. 0. 1999. Australian Ants: Their Biology and Identification. CSIRO Publishing, Collingwood, Melbourne.

Silverman, J., and Roulston, T. H. 2001. Acceptance and intake of gel and liquid sucrose compositions by the argentine ant (Hymenoptera : Formicidae). Journal of Economic Entomology 94: 511-515.

Stanley, M. C. 2004. Review of the efficacy of baits used for ant control and eradication., Landcare Research.

Stanley, M. C., and Robinson, W. A. 2007. Relative attractiveness of baits to Paratrechina longicornis (Hymenoptera : Formicidae). Journal of Economic Entomology 100: 509-516. 
Suarez, A. V., Holway, D. A., and Case, T. J. 2000. Prey selection in horned lizards following the invasion of Argentine ants in southern California. Ecological Applications 10: 711-725.

Suarez, A. V., Holway, D. A., and Case, T. J. 2001. Patterns of spread in biological invasions dominated by long-distance jump dispersal: Insights from Argentine ants. Proceedings of the National Academy of Sciences 98: 1095-1100.

Taylor, R. W. 1959. The Australian ant Iridomyrmex darwinianus (Forel) recorded in New Zealand. New Zealand Entomologist 2: 18-19.

Toft, R. J. 2010. Potential for winter/spring control of Argentine ants. Landcare Research.

Toft, R. J., and Rees, J. 2009. Laboratory comparison of Advion and Xstinguish ${ }^{\mathrm{TM}}$ for Argentine ant control. Report for Tasman District Council, Landcare Research.

Ulloa-Chacon, P., and Jaramillo, G. I. 2003. Effects of boric acid, fipronil, hydramethylnon, and diflubenzuron baits on colonies of ghost ants (Hymenoptera : Formicidae). Journal of Economic Entomology 96: 856-862.

Vega, S. Y., and Rust, M. K. 2001. The Argentine ant - A significant invasive species in agricultural, urban and natural environments. Sociobiology 37: 3-25.

Walters, A. C., and Mackay, D. A. 2003. An experimental study of the relative humidity preference and survival of the Argentine ant, Linepithema humile (Hymenoptera, Formicidae): comparisons with a native Iridomyrmex species in South Australia. Insectes Sociaux 50: 355-360.

Ward, D. F. 2009. Potential social, economic and biodiversity impacts of the Argentine ant, Linepithema humile, in the Hawke's Bay region. Landcare Research.

Ward, D. F., Stanley, M.,Forgie, S., Toft, R., and Rees, J. 2008. Ecological impacts of Argentine ants in New Zealand., pp. 16-18, Protect Magazine. Biosecurity Institute.

Ward, D. F., Green, C., Harris, R. J., Hartley, S., Lester, P. J., Stanley, M. C., Suckling, D. M., and Toft, R. J. 2010. Twenty years of Argentine ants in New Zealand: past research and future priorities for applied management. New Zealand Entomologist 33: 68-78.

Wild, A. L. 2004. Taxonomy and Distribution of the Argentine Ant, Linepithema humile (Hymenoptera: Formicidae). Annals of the Entomological Society of America 97: 1204-1215. 


\title{
Appendix 1:
}

\section{$\underline{\text { An experiment to examine Darwin's ants' protein preferences }}$}

\begin{abstract}
Aim
For the food preference experiments, I supplied field populations of both Argentine and Darwin's ants with a casein: water solution, to determine if this was a palatable and attractive food source. I introduced the casein solution in June 2010, prior to when the food preference experiments began. Argentine ants had a strong interest in casein protein, but Darwin's ants showed little interest. Darwin's ants' low interest in casein protein was assumed to be because it was winter and foraging preference for protein would be low. It was also assumed that as temperatures became warmer, Darwin's ants would require protein for reproduction and their interest in protein would increase. However this did not change and casein protein was consistently unattractive to Darwin's ants year round. Therefore I conducted an experiment comparing different protein sources to determine why Darwin's ants did not readily feed on casein protein.
\end{abstract}

\section{Methods}

Darwin's ants may not have found casein protein palatable as they may prefer other protein sources, they may not prefer the presentation of protein in a water soluble form and/or they have more highly preferred or more accessible forms of protein in their environment (Kay 2002).

To test these hypotheses, I set up five ceramic tiles $(20 \mathrm{~cm} \times 20 \mathrm{~cm})$ with eight different protein sources. Each tile contained a $2 \mathrm{~cm}^{3}$ amount of raw tuna, raw salmon, cooked chicken and cooked beef mince. The four liquid protein sources of $15 \%$ casein protein: water, entire raw egg, water mixed with canned tuna water and water mixed with canned salmon water were soaked onto a cotton wool square $(\sim 2 \mathrm{~cm} \times 2 \mathrm{~cm})$. The water mixtures containing either canned tuna water or salmon water consisted of $50 \%$ distilled water and 50\% canned tuna/salmon water. The canned tuna and salmon were both canned in spring water with no added flavourings and as little added salt as was 
possible based on availability. This was important to ensure the tuna and salmon were pure forms of protein and that any ants recruiting to these foods would be assumed to be because of the protein source itself. Each food source was placed approximately $2 \mathrm{~cm}$ apart from one another on the tile.

Each tile was placed at a different Darwin's ants site for approximately three hours (sites were spatially separated by $>100 \mathrm{~m}$ ). Over a three hour period, hourly numbers of ants were recorded. Similarly to the food preference tests, the highest number of ants was observed at the third hour of the experiment. The third hour of data was used to compare protein preferences.

\section{Results}

The lowest numbers of ants recruited to the raw egg and casein protein (Figure 1). Numbers of ants on the casein protein at any one time was less than five ants. Numbers on the raw egg protein at any one time was less than eight ants. Salmon and chicken were on average the most preferable sources of protein. On average, Darwin's ants preferred the protein sources that were in a solid form over the liquid protein forms.

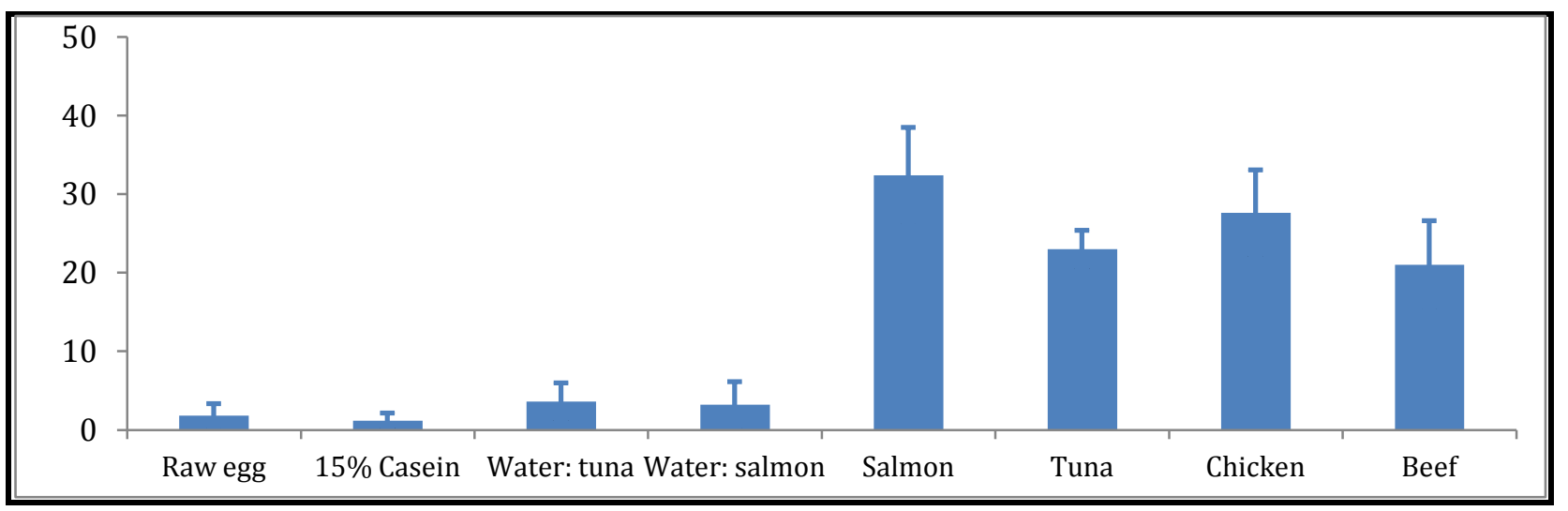

Figure 3.1. Mean number of Darwin's ants at the third hour of observations (+-SE) on different protein sources.

\section{Discussion}

There has been little research conducted on the protein preferences of Darwin's ants (Doleromyrma darwiniana), yet it has been noted that dead arthropods have been found 
in their nests indicating they have a broader diet than just carbohydrates (Keall and Somerfield 1980). Casein protein was chosen for both Argentine and Darwin's ants in my experiments as other studies have found casein to be palatable in many ant species (Kay 2002; Kay 2004), and I also wanted the protein sources to be consistent between ant species. Argentine ants also readily recruited to casein protein, even during winter, which suggests that Argentine ants may be less selective over protein sources than Darwin's ants.

In conclusion these experiments showed that casein was not an attractive source of protein when other forms of protein were offered. Although the salmon, tuna, chicken and beef were highly attractive, this may have been because they contained carbohydrates too which would have attracted Darwin's ants irrespective of protein. Darwin's ants still had an interest in other forms of protein indicating they were actively foraging for protein. It was initially thought that Darwin's ants may have refused the casein because they may have been able to gather it more quickly from other sources in their environment (Kay 2002). It may also have been possible that Darwin's ants refused casein because they may not have been able to sense the casein being present in low concentrations and therefore treated it as being no different to water.

\section{Literature cited}

Kay, A. 2002. Applying optimal foraging theory to assess nutrient availability ratios for ants. Ecology 83: 1935-1944.

Kay, A. 2004. The relative availabilities of complementary resources affect the feeding preferences of ant colonies. Behavioral Ecology 15: 63-70.

Keall, J. B., and Somerfield, K. G. 1980. The Australian ant Iridomyrmex darwinianus established in New Zealand (Hymenoptera: Formicidae). New Zealand Entomologist 7: 123-127. 